\title{
Phylogenetics of the Pezizaceae, with an Emphasis on Peziza
}

\section{Citation}

Hansen, Karen, Thomas Laessoe, and Donald H. Pfister. 2001. Phylogenetics of the Pezizaceae, with an emphasis on Peziza. Mycologia 93, no. 5: 958-990.

\section{Published Version}

http://dx.doi.org/10.2307/3761760

\section{Permanent link}

http://nrs.harvard.edu/urn-3:HUL.InstRepos:3153300

\section{Terms of Use}

This article was downloaded from Harvard University's DASH repository, and is made available under the terms and conditions applicable to Other Posted Material, as set forth at http:// nrs.harvard.edu/urn-3:HUL.InstRepos:dash.current.terms-of-use\#LAA

\section{Share Your Story}

The Harvard community has made this article openly available.

Please share how this access benefits you. Submit a story.

\section{Accessibility}




\section{Mycological Society of America}

Phylogenetics of the Pezizaceae, with an Emphasis on Peziza

Author(s): Karen Hansen, Thomas L[ae]ssoe, Donald H. Pfister

Source: Mycologia, Vol. 93, No. 5 (Sep. - Oct., 2001), pp. 958-990

Published by: Mycological Society of America

Stable URL: http://www.jstor.org/stable/3761760

Accessed: 05/06/2009 20:11

Your use of the JSTOR archive indicates your acceptance of JSTOR's Terms and Conditions of Use, available at http://www.jstor.org/page/info/about/policies/terms.jsp. JSTOR's Terms and Conditions of Use provides, in part, that unless you have obtained prior permission, you may not download an entire issue of a journal or multiple copies of articles, and you may use content in the JSTOR archive only for your personal, non-commercial use.

Please contact the publisher regarding any further use of this work. Publisher contact information may be obtained at http://www.jstor.org/action/showPublisher?publisherCode=mysa.

Each copy of any part of a JSTOR transmission must contain the same copyright notice that appears on the screen or printed page of such transmission.

JSTOR is a not-for-profit organization founded in 1995 to build trusted digital archives for scholarship. We work with the scholarly community to preserve their work and the materials they rely upon, and to build a common research platform that promotes the discovery and use of these resources. For more information about JSTOR, please contact support@jstor.org. 


\section{Phylogenetics of the Pezizaceae, with an emphasis on Peziza}

\author{
Karen Hansen ${ }^{1}$ \\ Thomas Læssøe \\ Department of Mycology, University of Copenhagen, \\ $\emptyset$ ster Farimagsgade 2 D, DK-1353 Copenhagen $K$, \\ Denmark
}

\section{Donald H. Pfister}

Harvard University Herbaria, Cambridge, Massachusetts, 02138 USA

\begin{abstract}
Phylogenetic relationships among members of the Pezizaceae were studied using 90 partial LSU rDNA sequences from 51 species of Peziza and 20 species from 8 additional epigeous genera of the Pezizaceae, viz. Boudiera, Iodophanus, Iodowynnea, Kimbropezia, Pachyella, Plicaria, Sarcosphaera and Scabropezia, and 5 hypogeous genera, viz. Amylascus, $\mathrm{Ca}$ zia, Hydnotryopsis, Ruhlandiella and Tirmania. To test the monophyly of the Pezizaceae and the relationships to the genera Marcelleina and Pfistera (Pyronemataceae), 6 species from the families Ascobolaceae, Morchellaceae and Pyronemataceae were included. Maximum parsimony and maximum likelihood analyses of these sequences suggest that the Pezizaceae is paraphyletic, because the non-amyloid Marcelleina is nested within it. If Marcelleina were transferred to the Pezizaceae, then the family would be monophyletic. Although the Pezizaceae is traditionally characterized by amyloid asci, our results indicate that the amyloid reaction is a symplesiomorphy, which has been lost in some lineages, e.g., in those including Marcelleina and Cazia. Nodes deep in the tree could not be resolved, but 7 groups of species (I-VII) are generally well supported or present in all trees. Peziza species, which constitute the core of the family, are present in all groups except group III, confirming the non-monophyly of the genus. The analyses suggest that the other included genera of the Pezizaceae are all nested within Peziza, the placement of Iodophanus being unresolved. The morphologically distinct Peziza gerardii, which forms a clade with Marcelleina, appears to be the sister group to the rest of the Pezizaceae. Morphological features were studied and evaluated in the context of the phylogeny. Distinct types of ascus amyloid reac-
\end{abstract}

Accepted for publication April 3, 2001.

${ }^{1}$ Corresponding author, Email: karenh@bot.ku.dk tions were found to support different rDNA lineages, e.g., a distinct amyloid ring zone at the apex is a synapomorphy for group IV, an intense and unrestricted amyloid reaction of the apex is mostly found in group VI, and asci that are weakly or diffusely amyloid in the entire length are present in group II. Other morphological features, such as spore surface relief, guttulation, excipulum structure and pigments, while not free from homoplasy, do support the groupings. Anamorphs likewise provide clues to higher-order relationships within the Pezizaceae. Several macro- and micromorphological features, however, appear to have evolved several times independently, including ascomatal form and habit (epigeous, semihypogeous or hypogeous), spore discharge mechanisms, and spore shape. Parsimony-based optimization of character states on our phylogenetic trees suggested that transitions to truffle and truffle-like forms evolved at least three times within the Pezizaceae (in group III, V and VI). The 9 hypogeous species included are nested in lineages with epigeous pezizaceous taxa. Species with apothecia of various shapes and with forcible spore discharge are spread among all groups and the apothecium is suggested to be symplesiomorphic in the Pezizaceae. The results indicate that the apothecia forming Pezizaceae have given rise to at least 3 different forms of hypogeous ascomata without forcible spore discharge: ptychothecia, stereothecia and exothecia.

Key Words: ascus amyloid reactions, epigeous-hypogeous evolution, molecular phylogeny, nLSU rDNA, Pezizales, systematics

\section{INTRODUCTION}

The Pezizaceae (Pezizales) displays great variation in ascomatal forms. It includes taxa that produce epigeous, sessile or stipitate, cupulate, discoid, turbinate, pulvinate or sparassoid ascomata, or semi-hypogeous to hypogeous, closed, folded to solid ascomata (FIGS. 1-21). The ascomata range in size from a few $\mathrm{mm}$ to more than $10 \mathrm{~cm}$ in diam, and are often fleshy, soft and brittle. Anatomical and biochemical diversity is found in characters such as spore discharge mechanism; amyloid reaction of the ascus; spore shape, color, ornamentation, and guttulation; pigmentation of the paraphyses; and excipulum structure (TABLE I). 

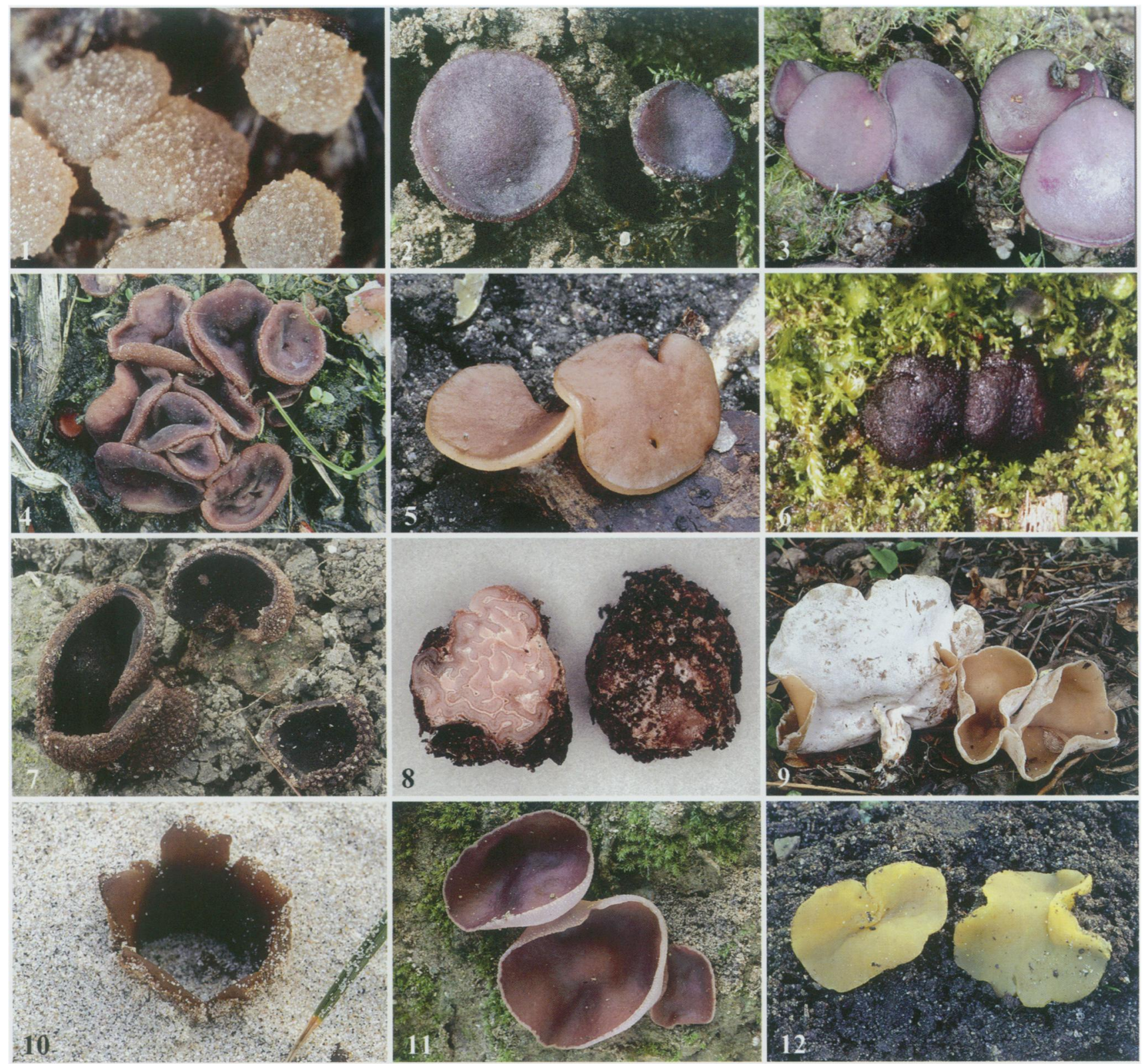

FIGS. 1-12. Ascoma forms and color variation in the Pezizaceae (group I-IV). 1. Pulvinate apothecia with protruding asci. Iodophanus carneus (JHP-00.027, C) $\times 15$. 2-3. Group I. Discoid apothecia on broad obconical bases. 2. Peziza gerardii (KH98-86, C) $\times$ 3. 3. Marcelleina persoonii (TL-5346, C) $\times 3$. 4. Group II. Peziza subisabellina (RK83.115, herb. Roy Kristiansen) $\times 1.3$. 5-8. Group III. 5. Pachyella punctispora $(\mathrm{KH}-98-77, \mathrm{C}) \times 1.5$. 6 . Turbinate apothecia with a convex hymenium. Boudiera dennisii (JHP-93.095, C) $\times 6$. 7. Highly pustulate outer surface. Scabropezia flavovirens (Fuckel) Dissing \& Pfister (KH-97-68, C) $\times 2$. 8. Stereothecium. Amylascus. (5728, OSC) $\times 1.5$. 9-10. Group IVa. 9. Cup-shaped, shortly stipitate apothecia. Peziza arvernensis $(\mathrm{KH}-98-08, \mathrm{C}) \times 0.4$. 10. Peziza ammophila $(\mathrm{KH}-98-88, \mathrm{C}) \times 0.8$. 11-12. Group IVb. 11. Peziza exogelatinosa $(\mathrm{KH}-$ 97-75, C) $\times 0.8$. 12. Peziza subcitrina $(\mathrm{KH}-97-133, \mathrm{C}) \times 1.3$.

Photos: 1, 2, 6, 7, 11 J.H. Petersen. 5, 9, 12 K. Hansen. 8 M. Castellano. 10 S.A. Elborne. 3 T. Læssøe. 4 R. Kristiansen.

Ecologically, the family covers a broad range of niches, fruiting on all types of soil, sand, clay, limestone, burnt ground, dung and wood. Many species are known to prefer soil with a high $\mathrm{pH}$ and in some cases a low content of organic matter (Petersen 1967, $1985)$. The family is primarily restricted to temperate zones and arctic-alpine areas, although a few strictly tropical taxa are known. The majority of species are considered to be saprotrophs, although most hypogeous and a few epigeous species are claimed to be ectomycorrhizal (Maia et al 1996 and references therein), but in general their trophic statuses are not 
TABle I. Characters used in the delimitation of genera in the Pezizaceae (based on published and original observations)

\begin{tabular}{|c|c|c|c|c|c|}
\hline Genus & $\begin{array}{c}\text { Ascoma: } \\
\text { position }^{\text {b; }} \\
+/- \\
\text { forcible } \\
\text { spore dis- } \\
\text { charge }\end{array}$ & $\begin{array}{l}\text { Ascoma: type; } \\
\text { shape when } \\
\text { epigeous }\end{array}$ & $\begin{array}{c}\text { Ascus: }+/- \text { amyloid; } \\
\text { type of } \\
\text { amyloid reaction }\end{array}$ & $\begin{array}{l}\text { Spore: shape; } \\
\text { guttulation }\end{array}$ & $\begin{array}{l}\text { Spore: color; +/- } \\
\text { ornamentation }\end{array}$ \\
\hline Amylascus & $\begin{array}{c}\text { hy, se; } \\
-\end{array}$ & $\begin{array}{l}\text { Ptychothecium to } \\
\text { stereothecium }\end{array}$ & $\begin{array}{l}\text { +; weakly over the } \\
\text { entire length }\end{array}$ & Globose; 1 or several & $\begin{array}{l}\text { Hyaline to pale } \\
\text { brown; + spines, } \\
\text { rods or cones }\end{array}$ \\
\hline Boudiera & ep; + & $\begin{array}{l}\text { Apothecium, subglo- } \\
\text { bose, turbinate to } \\
\text { pulvinate }\end{array}$ & $\begin{array}{l}+ \text {; weakly over the } \\
\text { entire length }\end{array}$ & Globose; 1 or several & $\begin{array}{l}\text { Pale brown; + echi- } \\
\text { nulate to reticu- } \\
\text { late }\end{array}$ \\
\hline $\operatorname{Cazia}^{\mathrm{a}}$ & hy; - & Stereothecium & - & Ellipsoid; 1 & $\begin{array}{l}\text { Hyaline; + minutely } \\
\text { warty-reticulate }\end{array}$ \\
\hline Hapsidomyces $^{\mathrm{a}}$ & ep; + & $\begin{array}{l}\text { Apothecium, turbi- } \\
\text { nate }\end{array}$ & $\begin{array}{l}+ \text {; weakly over the } \\
\text { entire length }\end{array}$ & Globose; 0 & $\begin{array}{l}\text { Hyaline to pale yel- } \\
\text { low; + reticulate } \\
\text { and spiny }\end{array}$ \\
\hline Hydnobolites & hy; - & Stereothecium & $\begin{array}{l}+/- \text {; weakly }(2 \% \\
\text { KOH pretreat- } \\
\text { ment })\end{array}$ & Globose; 0 & $\begin{array}{l}\text { Hyaline to pale } \\
\text { brown; + reticu- } \\
\text { late }\end{array}$ \\
\hline Hydnotryopsis & hy; - & Stereothecium & $\begin{array}{l}+ \text {; diffusely over the } \\
\text { entire length }\end{array}$ & Ellipsoid; ? & $\begin{array}{c}\text { Hyaline to brownish } \\
\text { yellow; + warty to } \\
\text { pitted to ridged }\end{array}$ \\
\hline Iodophanus & ep; + & $\begin{array}{l}\text { Apothecium, pulvi- } \\
\text { nate }\end{array}$ & $\begin{array}{l}+ \text {; weakly over the } \\
\text { entire length }\end{array}$ & $\begin{array}{l}\text { Ellipsoid to broadly } \\
\text { ellipsoid; } 0\end{array}$ & $\begin{array}{l}\text { Hyaline; + warty or } \\
\text { episporium wrin- } \\
\text { kled }\end{array}$ \\
\hline Iodowynnea & ep; + & $\begin{array}{l}\text { Apothecium, convo- } \\
\text { luted to highly } \\
\text { folded, arising } \\
\text { from a hypogeous } \\
\text { stipe }\end{array}$ & $\begin{array}{l}+ \text {; intensely over the } \\
\text { entire length }\end{array}$ & $\begin{array}{l}\text { Ellipsoid; } 1 \text { or } 2 \text {, } \\
\text { rarely several }\end{array}$ & $\begin{array}{l}\text { Hyaline; + longitu- } \\
\text { dinally ridged and } \\
\text { warty }\end{array}$ \\
\hline Kimbropezia & $\mathrm{ep} ;+$ & Apothecium, discoid & $\begin{array}{l}+ \text {; intensely over the } \\
\quad \text { apex }\end{array}$ & Ellipsoid; 0 & Hyaline; - \\
\hline Mycoclelandia & $\begin{array}{c}\text { hy, se; } \\
-\end{array}$ & Ptychothecium & $\begin{array}{l}+ \text {; diffusely, more } \\
\text { intense near the } \\
\text { apex }\end{array}$ & $\begin{array}{l}\text { Broadly ellipsoid to } \\
\text { subglobose; } 1 \text { or } 2\end{array}$ & Hyaline; - \\
\hline Pachyella & ep; + & $\begin{array}{l}\text { Apothecium, discoid, } \\
\text { flat to pulvinate, } \\
\text { broadly attached } \\
\text { to the substrate }\end{array}$ & $\begin{array}{l}+ \text {; diffusely over the } \\
\text { entire length }\end{array}$ & Ellipsoid; 2 & $\begin{array}{l}\text { Hyaline; }-/+ \text { warty, } \\
\quad \text { ridged }\end{array}$ \\
\hline Pachyphloeus & hy; - & Stereothecium & $\begin{array}{l} \pm \text {; weakly over the } \\
\text { entire length }\end{array}$ & Globose; 0 ? & $\begin{array}{l}\text { Hyaline to pale } \\
\text { brown; + spinose } \\
\text { to verrucose, }+/- \\
\text { embedded in mu- } \\
\text { cilage }\end{array}$ \\
\hline Peziza & $\begin{array}{l}\text { ep, } \\
\text { rarely } \\
\text { se, } \\
\text { hy; + } \\
\text { rarely } \\
\text { - }\end{array}$ & $\begin{array}{l}\text { Apothecium, discoid } \\
\text { to cupulate, rarely } \\
\text { sparassoid, or } \\
\text { rarely ptychothe- } \\
\text { cium }\end{array}$ & $\begin{array}{l}+ \text {; ring zone at the } \\
\text { apex, intensely un- } \\
\text { restricted over the } \\
\text { apex or evenly } \\
\text { over the entire } \\
\text { length (diffusely, } \\
\text { weakly or intense- } \\
\text { ly) }\end{array}$ & $\begin{array}{l}\text { Ellipsoid or fusi- } \\
\text { form; } 0,2 \text {-or } \\
\text { multi-guttulate, } \\
\text { rarely } 1\end{array}$ & $\begin{array}{l}\text { Hyaline or pale } \\
\text { brown; }-/+ \\
\text { warty, ridged to } \\
\text { reticulate, spiny, } \\
\text { apiculate }\end{array}$ \\
\hline
\end{tabular}


Paraphyses: pigments; gelatinous matrix; epithecium

Absent

Hyaline or brownish walls

Paraphyses present: pigments?

Yellowish contents

Absent

Paraphyses present: pigments?

Usually containing carotenoid pigments

Hyaline

Hyaline

Hyaline

Dark granules in the apical cells

Absent

$+/$ - pigmented granules; +/- embedded in granular matrix

Excipulum: outer

Outermost textura globulosa to angularis, giving rise to surface tomentum. Inner layer of broad hyphae, mixed with inflated cells

Textura globulosa to angularis

Textura intricata, at septa, the cells often inflated

Textura globulosa to angularis

Textura globulosa ( \pm isodiametric cells) with brownish, amorphous material in the intercellular spaces

Textura globulosa ( \pm isodiametric cells), sometimes with interwove hyphae

Textura globulosa to angularis, sometimes with interwoven hyphae

Textura globulosa intermixed with hyphae, outermost cells arranged in short chains

Textura intricata, with very short hyphae, extending towards outside

Textura intricata or textura globulosa

Textura globulosa to angularis, outer cells terminating in flexuous hairs embedded in a gelatinous matrix

Subangular to globose isodiametric cells, on outside scabrous to verrucose

Textura globulosa or textura angularis, of large, thinwalled cells $+/-$ interwoven hyphae, or smaller globose cells elongating to a hyphoid layer towards the outside
Trophic status; substrate $^{c} \quad$ Anamorphs

Excipulum: medullary

ec ?; te

Unknown

large cells

Dense textura intricata

sa ?, ec ?; te

Unknown

Textura intricata

ec ?; te

Unknown

Textura intricata

sa; co

Unknown

Textura globulosa ( \pm isodiametric cells), or textura intricata

Textura intricata

ec ?; te

Unknown

Textura intricata
sa ?; te, co, py

Textura globulosa intermixed with hy-

ec ?; te

Unknown

phae

A layer of textura intri-

sa ?; te

Unknown cata, between two layers of textura angularis to globulosa

Textura globulosa, of large, thin-walled cells

Textura intricata $+/-$ gelatinous matrix

Isodiametric cells

ec ?; te

Glischroderma?
One, two or more layers, of textura globulosa or textura angularis, of large, thin walled cells $+/-$ interwoven hyphae, or of parallel hyphae sa, ec; te, co, Oedocephalum, py, li Chromelosporium, Chromelosporium-like, or hyaline to colored, 0-3 septate resting spores 
TABLE I. Continued

\begin{tabular}{|c|c|c|c|c|c|}
\hline Genus & $\begin{array}{c}\text { Ascoma: } \\
\text { position } \\
+/- \\
\text { forcible } \\
\text { spore dis- } \\
\text { charge }\end{array}$ & $\begin{array}{l}\text { Ascoma: type; } \\
\text { shape when } \\
\text { epigeous }\end{array}$ & $\begin{array}{c}\text { Ascus: }+/- \text { amyloid; } \\
\text { type of } \\
\text { amyloid reaction }\end{array}$ & $\begin{array}{l}\text { Spore: shape; } \\
\text { guttulation }\end{array}$ & $\begin{array}{l}\text { Spore: color; }+/- \\
\text { ornamentation }\end{array}$ \\
\hline Plicaria & ep; + & $\begin{array}{l}\text { Apothecium, discoid } \\
\text { to cupulate }\end{array}$ & $\begin{array}{l}+ \text {; weakly over the } \\
\text { entire length }\end{array}$ & $\begin{array}{l}\text { Globose; few to mul- } \\
\text { ti-guttulate }\end{array}$ & $\begin{array}{l}\text { Pale brown; }-/+ \\
\text { warty, spiny, reticu- } \\
\text { late }\end{array}$ \\
\hline Rhodopeziza $a^{\mathrm{a}}$ & ep; + & $\begin{array}{l}\text { Apothecium, cupu- } \\
\text { late }\end{array}$ & $\begin{array}{l}+ \text {; over the entire } \\
\text { length }\end{array}$ & $\begin{array}{l}\text { Broadly ellipsoid; } 1 \\
\text { small evanescent } \\
\text { guttule }\end{array}$ & $\begin{array}{l}\text { Pale yellowish; + tu- } \\
\text { berculate }\end{array}$ \\
\hline Ruhlandiella & se; - & Exothecium & $\begin{array}{l}+ \text {; weakly over the } \\
\text { entire length }\end{array}$ & Globose; 1 & $\begin{array}{l}\text { Pale brown; + retic- } \\
\text { ulate-areolate }\end{array}$ \\
\hline Sarcosphaera ${ }^{\mathrm{a}}$ & $\begin{array}{c}\text { ep, se; } \\
+\end{array}$ & $\begin{array}{l}\text { Apothecium, hollow, } \\
\text { initially hypoge- } \\
\text { ous, becoming ex- } \\
\text { posed and split } \\
\text { into acute rays }\end{array}$ & $\begin{array}{l}+ \text {; weakly over the } \\
\text { entire length (a } \\
\text { little stronger at } \\
\text { the apex) }\end{array}$ & Ellipsoid; 2 & Hyaline; + low warty \\
\hline Scabropezia & ep; + & $\begin{array}{l}\text { Apothecium, cupu- } \\
\text { late }\end{array}$ & $\begin{array}{l}+ \text {; over the entire } \\
\text { length }\end{array}$ & Globose; 1 & $\begin{array}{l}\text { Pale brown; + trun- } \\
\text { cate or delicate } \\
\text { warts }\end{array}$ \\
\hline Sphaerozone $e^{\mathrm{a}}$ & hy, se; & Exothecium & $\begin{array}{l}+ \text {; weakly, over the } \\
\text { entire length }\end{array}$ & Globose; 0 & $\begin{array}{l}\text { Reddish brown; + } \\
\text { irregular warty }\end{array}$ \\
\hline Terfezia & hy; - & Stereothecium & - & Globose; 0 & $\begin{array}{l}\text { Hyaline to pale } \\
\text { brown; + spiny, } \\
\text { papillate, reticu- } \\
\text { late, }-/+ \text { muci- } \\
\text { lage-embedded }\end{array}$ \\
\hline Tirmania & hy; - & Stereothecium & $\begin{array}{l}+ \text {; diffusely, +/- } \\
\text { weakly }\end{array}$ & $\begin{array}{l}\text { Globose to broadly } \\
\text { ellipsoid; } 1\end{array}$ & $\begin{array}{l}\text { Hyaline; }-/+ \text { mi- } \\
\text { nutely roughened }\end{array}$ \\
\hline
\end{tabular}

well studied. A study by Warcup (1990), with single spore isolation and incubation experiments did, however, show several species, both epigeous and hypogeous, to be ectomycorrhizal.

Eriksson (2000) lists 19 genera in the Pezizaceae, with a circumscription based mainly on Rifai (1968), Kimbrough (1970) and Trappe (1979). Recent molecular phylogenetic studies have led to the inclusion of Pachyphloeus and Terfezia in the family (Norman and Egger 1999, Percudani et al 1999) (TABle I). The Pezizaceae is chiefly characterized by amyloid asci, a feature shared only with the Ascobolaceae within the Pezizales. The spores are uninucleate, usually thin-walled, globose, ellipsoid or fusiform, hyaline or pale brown, smooth or with cyanophilic or- naments. The excipulum consists, at least partly, of large isodiametric cells. In addition, ultrastructural and refined cytochemical studies have led to further delimiting characters such as the presence of electron-opaque convex and biconvex bands in septal pores of the ascal bases (so far recorded in Peziza, Plicaria, Iodophanus, Sarcosphaera, Pachyella and Hydnobolites) (Curry and Kimbrough 1983, Kimbrough and Curry 1985, Kimbrough et al 1991, Kimbrough 1994).

Molecular phylogenetic studies of the Pezizales to date have included relatively few taxa from the groups with amyloid asci. With regard to the Pezizaceae, the work of Norman and Egger $(1996,1999)$ deserves special note, because it provides broader 


\begin{tabular}{|c|c|c|c|c|}
\hline $\begin{array}{l}\text { Paraphyses: pigments; } \\
\text { gelatinous } \\
\text { matrix; epithecium }\end{array}$ & Excipulum: outer & Excipulum: medullary & $\begin{array}{l}\text { Trophic status; } \\
\text { substrate }^{c}\end{array}$ & Anamorphs \\
\hline $\begin{array}{l}\text { Embedded in dark } \\
\text { granular matrix }\end{array}$ & $\begin{array}{l}\text { Textura globulosa to angu- } \\
\text { laris, and intermixed } \\
\text { broad hyphae }\end{array}$ & $\begin{array}{l}\text { Textura globulosa and } \\
\text { intermixed broad } \\
\text { hyphae }\end{array}$ & sa ?, ec; py & Chromelosporium \\
\hline $\begin{array}{l}\text { Orange granules (ca- } \\
\text { rotenoid granules) }\end{array}$ & $\begin{array}{l}\text { Textura globulosa to angu- } \\
\text { laris, of subglobose to po- } \\
\text { lygonal cells }\end{array}$ & $\begin{array}{l}\text { Small textura globulo- } \\
\text { sa angularis, occa- } \\
\text { sionally intermixed } \\
\text { with hyphae }\end{array}$ & sa ?; te & Unknown \\
\hline $\begin{array}{l}\text { Gelatinous sheath; ex- } \\
\text { ceeding the asci }\end{array}$ & $\begin{array}{l}\text { Textura globulosa to angu- } \\
\text { laris, thick-walled cells }\end{array}$ & $\begin{array}{l}\text { Textura globulosa to } \\
\text { angularis }\end{array}$ & ec; te & $\begin{array}{l}\text { Chromelospor- } \\
\text { ium-like }\end{array}$ \\
\hline Brownish contents & $\begin{array}{l}\text { Textura epidermoidea, to } \\
\text { textura prismatica towards } \\
\text { the outside }\end{array}$ & Textura globulosa & ec ?; te & Unknown \\
\hline $\begin{array}{l}\text { Small brownish guttu- } \\
\text { les; embedded in a } \\
\text { coloured, granular } \\
\text { matrix }\end{array}$ & $\begin{array}{l}\text { Textura globulosa, outer- } \\
\text { most cells thick-walled, } \\
\text { forming conical pustules }\end{array}$ & Textura intricata & $\begin{array}{l}\text { sa ?, ec ?; te, } \\
\quad \text { li }\end{array}$ & Glischroderma? \\
\hline Exceeding the asci & $\begin{array}{l}\text { Textura globulosa to angu- } \\
\text { laris, cells thick-walled }\end{array}$ & $\begin{array}{l}\text { Textura globulosa to } \\
\text { angularis }\end{array}$ & ec ?; te & Unknown \\
\hline Absent & $\begin{array}{l}\text { Textura intricata, of broad } \\
\text { hyphae with inflated cells }\end{array}$ & $\begin{array}{l}\text { Textura intricata, of } \\
\text { broad hyphae with } \\
\text { inflated cells }\end{array}$ & ec ?; te & Unknown \\
\hline Absent & $\begin{array}{l}\text { Textura intricata, of broad, } \\
\text { thin-walled hyphae and } \\
\text { many inflated cells }\end{array}$ & $\begin{array}{l}\text { Textura intricata, of } \\
\text { broad, thin-walled } \\
\text { hyphae and many } \\
\text { inflated cells }\end{array}$ & ec ?; te & Unknown \\
\hline
\end{tabular}

sampling of the family than any previous study. Nevertheless, further sampling of Peziza species and inclusion of additional genera, as described here, are necessary to critically assess generic limits within the family and to work toward a phylogenetic classification. The main objectives of this research were: i) to resolve the major lineages within the Pezizaceae, especially within Peziza, using LSU rDNA sequences, and to compare these with previous morpho-taxonomic classifications, ii) to explore the circumscription of Peziza itself, and iii) to evaluate and refine morphological characters previously used in the delimitation of genera within the Pezizaceae. The results should give direction to further morphological and molecular studies.

\section{BACKGROUND INFORMATION}

The family: delimitation and important morphological characters.-For nomenclatural purposes the Peziza- ceae can be traced to Dumortier (1829) (Hawksworth and David 1989), as a family of the order Fungarieae (fungi with a distinct external hymenium), to include genera with the spores born on the upper surface of a cup-shaped receptacle. Dumortier's circumscription was essentially the same as used by Fries (1822, as "Pezizeæ"), but Fries did not use a consistent method of ranking in his system, and therefore Fries is not accepted as author of the Pezizaceae contrary to the use by, e.g., Eckblad (1968), Kimbrough (1970) and Korf (1972). Dumortier (1829) listed Peziza and Ascobolus, along with other genera of the discomycetes, Stictis, Bulgaria, Tympanis, Cenangium, Patellaria and Helotium, and two genera of basidiomycetes, Solenia and Ditiola. This system was based solely on macroscopic features and has long been regarded as artificial.

Boudier (1885) was the first to delimit a group, "the Aleuriés," which more or less circumscribes the 
core of the Pezizaceae as we recognize it today. The group was placed in the "division Operculés," distinguished by asci that open with an operculum. Besides the presence or absence of an operculum, Boudier introduced and used further important microscopic characters, such as the amyloid reaction of asci, spore shape and number of oil guttules in the spores in his classification of the "fleshy discomycetes." The "Aleuriés" was distinguished by amyloid asci and in general having cup-shaped, sessile ascomata without hairs on the receptacle. The genera Lepidotia Boud., Aleuria (Fr.) Gill. and Galactinia (Cooke) Boud. (= Peziza), Sarcosphaera, Sphaerosoma Klotzsch, and Plicaria were included. Later Boudier (1907) treated the group at tribus level ("Aleuriées") and added his new genus Pachyella, but Sphaerosoma was excluded. Pachyella was segregated from Peziza and Psilopezia Berk. on the basis of the pulvinate to convex apothecia and lack of or only weakly amyloid asci. The absence of an amyloid reaction for taxa in the tribe was contrary to the definition of "Aleuriées," but Boudier also knowingly included species in Plicaria that had non-amyloid asci.

Boudier's (1907) circumscription of the Aleuriées was generally followed by Le Gal (1947, as tribus Aleurieae), Rifai (1968), Eckblad (1968) and Korf (1972, 1973b) (as Pezizaceae), and Dennis (1981, as tribus Pezizeae). Additional characters, such as spore ornamentation of cyanophilic material (Le Gal 1947), uninucleate spores (Berthet 1964a), absence of carotenoid pigments (Arpin 1969) and the anatomy of the ascomata, consisting of mostly large isodiametric cells, were discovered and used to refine the limits of the family. In culture, many species of the Pezizaceae were found to produce Oedocephalum or Chromelosporium conidial states (Rifai 1968).

Trappe (1979) emended the family to include hypogeous taxa with chambered or marbled glebae and cylindric to saccate asci which lacked functional opercula. He recognized the artificial nature of the Tuberales, abandoned the order and assigned most taxa to families within the Pezizales. Hypogeous species of Peziza, and the genera Mycoclelandia, Hydnotryopsis, Amylascus and Tirmania were accepted in the Pezizaceae. Trappe considered the hypogeous taxa to be derived from various epigeous taxa within the family. This hypothesis was based primarily on similarities in the anatomy of the excipulum and on the presence of amyloid asci. Currently 10 genera, almost half of the genera accepted in the Pezizaceae, have semi-hypogeous to hypogeous ascomata (Eriksson 2000, TABLE I), while six hypogeous species are placed in $\mathrm{Pe}$ $z i z a$ (e.g., Figs. 17-18) (Trappe 1979).

The amyloid reaction. Amyloid asci were described by Nylander (1868), Karsten (1869) and Boudier
(1879) in a number of species of Peziza and Ascobolus Pers. Korf (1972) attached some importance to ascus amyloid reactions. He recognized the Pezizaceae for taxa with ascus amyloid reactions: i) in an apical ring, ii) over the apex, or iii) rarely in their whole length. Taxa in the Ascobolaceae tribus Iodophaneae were described as having diffusely amyloid asci (tribus Ascoboleae showed non-amyloid or diffusely amyloid asci). Nevertheless, Korf included Pachyella, characterized by diffusely amyloid asci, in the Pezizaceae. Except for the genera Pachyella, Iodophanus and Boudiera, the location and extent of the amyloid reaction have not been used as characters to delimit taxa within the Pezizaceae. Within the Ascobolaceae, differences in ascus reactions were noticed for some sections in the genus Ascobolus: intensely amyloid in sect. Dasyobolus (Sacc.) Brumm. (in all but one species), faintly amyloid or none at all in several mainly terrestrial and lignicolous species of sect. Ascobolus, and non-amyloid in sect. Pseudoascodesmis Brumm. (van Brummelen 1967). All species in the remaining four sections of Ascobolus showed a "general" amyloid reaction of the ascus wall. Van Brummelen (1967) found the intensity of the reaction to be constant for each species although significant differences existed between related species. A diffuse amyloid reaction was described by Pfister (1973) in Pachyella as "not restricted to the apex of the ascus, nor is it in the form of a J + ring at the apex of the ascus," and that it "is present either as an external layer on the ascus wall (which may separate from the ascus wall proper), or occurs in the gel which surrounds the asci and paraphyses and is not restricted to the wall."

Morphological and cytochemical studies of amyloid asci were performed on five species of the Pezizaceae and Ascobolaceae, using light microscopy and transmission electron microscopy (TEM) (Samuelson 1978). The amyloid site in Peziza succosa, Saccobolus depauperatus (Berk. and Broome) E.C. Hansen and Thecotheus pelletieri (Crouan) Boud. appeared to be an exogenous mucilaginous coat, whereas in Iodophanus granulipolaris Kimbrough it appeared to be the ascal wall proper. However, Samuelson stated that the amyloid reaction may be the result of more than one site of activity. Peziza succosa was strongly but unrestrictedly amyloid over the apex ("10-14 $\mu$ m down the sides of the ascal wall"). Peziza species with a distinct amyloid ring zone at the apex were not studied. According to van Brummelen (1978) the site of the amyloid reaction is strictly confined to an extra-ascal layer, the periascus (a mucilagenous substance), which varies in thickness. In Boudiera and Iodophanus it is more or less uniform, but in Peziza ammophila and $P$. succosella it develops into a ring-shaped thickening at the apex. In $P$. ammophila a thick ring with 
an indented central portion forms, whereas in $P$. succosella the periascus is considerably thickened but uniformly so over the ascus apex (van Brummelen 1978: figs. 7, 8). Such ultrastructural studies help to explain the variation in the amyloid reaction of asci, which is observed in the Pezizaceae.

The genera: delimitation and relationships.-Epigeous genera. Peziza Fr. (1822) is the largest genus within the Pezizales, with approximately 100 currently accepted species (Hohmeyer 1986, Korf 1972). It is a complex and heterogeneous assemblage, that constitutes the core of the Pezizaceae. Although many keys (Dissing 2000, Hohmeyer 1986, Häffner 1995, Le Gal 1941, Maas Geesteranus 1967, Moser 1963, Romagnesi 1978) and descriptions (e.g., Donadini 1978, 1979a, b, 1980a, Moravec 1985) of European species exist, Peziza has never been monographed and the infrageneric relationships are poorly understood. A number of subgenera and sections have been proposed, but only few attempts to provide a coherent system have been made (Donadini 1977, 1978). Furthermore, controversy has surrounded the generic delimitation of Peziza. Recent molecular studies suggest that the genus is not monophyletic, but rather is composed of at least two distinct clades (Norman and Egger 1996, 1999).

The nomenclature of Peziza is complicated on several counts. It is a pre-starting point name originating from Dillenius (1719). It has been applied to a number of cup-shaped fungi including both basidiomycetes and ascomycetes. Linnaeus (1753) adopted the name Peziza in Species Plantarum, the starting point work, for a group of fungi now referred to Cyathus Willd. (Basidiomycota) (Dennis 1983). Post-linnaean authors, particularly Bulliard (1791) and Persoon (1801), included primarily discomycetes, both operculate and inoperculate, in Peziza, thus making important contributions to the modern concept of the genus. Since Fries (1822) adopted the concept of these authors (not Linnaeus's concept) and placed what became the lectotype of Peziza L. (= Peziza lentifera $\mathrm{L} .=$ Cyathus olla Pers.) in Nidularia Fr. (Dennis 1983), Fries can be considered as having described Peziza as a new genus with a sanctioned status (Yao et al 1995). Peziza in the sense of Fries has been lectotypified by P. vesiculosa Bull.: Fr. (Wakefield 1939).

Boudier $(1885,1907)$ used two genera for taxa now placed in Peziza. Aleuria emend. Boud. non Fuckel for ellipsoid-spored species without oil guttules and Galactinia for ellipsoid-spored species with two guttules. Le Gal $(1941,1947)$ followed Boudier, but later (1953a) united the genera Aleuria and Galactinia in Galactinia with two sections: "Eguttulisporæ" nom illeg. and "Guttulisporæ" nom illeg. (corresponding to Aleuria and Galactinia sensu Boud. respectively). Le Gal abandoned Peziza as a "nomen confusum." The most recent classifications (Dennis 1981, Dissing and Pfister 1981, Dissing 2000, Eckblad 1968, Rifai 1968) follow Le Gal's (1953a) circumscription of the genus, but under the name $\mathrm{Pe}$ ziza. As such, Peziza is defined as having epigeous, discoid to cupulate apothecia, a few $\mathrm{mm}$ to ca $15 \mathrm{~cm}$ in diam, sessile or with a short stipe (FIGs. 2, 4, 9-12, 15, 20-21), amyloid asci, ellipsoid or rarely fusiform spores and an excipulum most often stratified in two or more layers of globose thin-walled cells intermixed with hyphae or a hyphal layer; lactiferous hyphae may be present. We have adopted this circumscription as the starting point for taxonomic comparisons in this study. Nevertheless, a few species are placed in the genus which produce more unusual ascomatal forms, i.e., sparassoid (Boudier 1899, Korf 1973a) or hypogeous, closed, hollow, often folded ascomata (FIGS. 17-18) (Burdsall 1968, Trappe 1979). The hypogeous forms have persistent hymenia and amyloid asci, but lack forcible spore discharge (TABLE I).

Sarcosphaera Auersw. (1869) was segregated from Peziza on the basis of its macro-morphology and initial hypogeous development. It produces large, enclosed, hollow apothecia, initially underground, which as they mature, usually become exposed and split into irregular acute rays (FIG. 13). The asci mature before the apothecia open, but are in organized hymenia, and the spores are forcibly discharged. Whether to recognize Sarcosphaera as distinct from Peziza has been questionable. Eckblad (1968) did not recognize Sarcosphaera as a distinct genus, and treated the species in Peziza. However, most contemporary taxonomists accept Sarcosphaera (Pouzar 1972, Korf 1973b, Pfister 1979a, Dissing 2000).

Plicaria Fuckel (1870) was introduced to accommodate species mostly treated by modern authors as Peziza and Plicaria, with both ellipsoid and globose spores, united by a few characters, e.g., thick-walled, brownish, ornamented spores. Peziza vesiculosa and others were placed in Pustularia Fuckel, while Peziza in Fuckel's classification included small stipitate inoperculate discomycetes. Fuckel erected Aleuria Fuckel for the non-amyloid, P. aurantia Pers. (the modern accepted concept of Aleuria). Boudier (1885) restricted Plicaria to the globose-spored species and was followed by most contemporary and later workers. Rehm (1894) used Plicaria, for only ellipsoid-spored species with amyloid asci, and erected Plicariella (Sacc.) Rehm for the globose-spored species; he rejected the name Peziza. Some authors have maintained Plicaria emend. Boud. as a separate genus (Eckblad 1968, Rifai 1968, Dennis 1981, Dissing and Pfister 1981, Hirsch 1985, Norman and Egger 

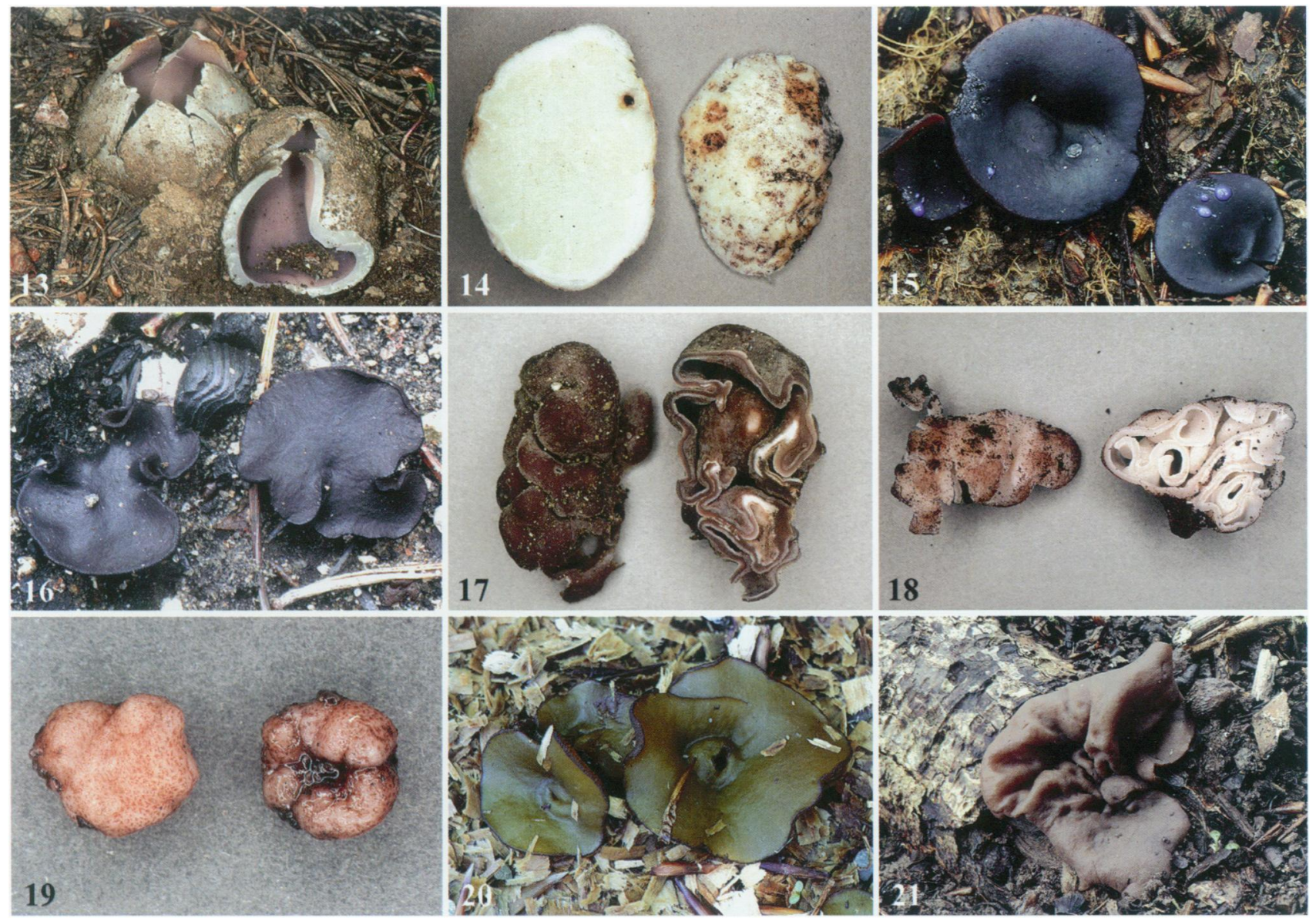

FIGS. 13-21. Ascoma forms and color variation in the Pezizaceae (group V-VII). 13-14. Group V. 13. Sarcosphaera coronaria $\times 0.4$. 14. Stereothecium. Hydnotryopsis setchellii (Trappe 19134, OSC) $\times 1.2$. 15-19. Group VI. 15. Peziza saniosa (JHP93.193, C) $\times 1$. 16. On burnt ground. Plicaria trachycarpa $($ KH-97-89, C) $\times 1.3$. 17. Ptychothecium. Peziza ellipsospora $($ Trappe 12996, OSC) $\times 1.3$. 18. Ptychothecium. Peziza whitei (M1445, OSC) $\times 1$. 19. Exothecium. Ruhlandiella berolinensis (12355, OSC) $\times 1$. 20. Group VIIa. Peziza polaripapulata $(\mathrm{KS}-95-10, \mathrm{C}) \times 0.8$. 21. Peziza retrocurvata $(\mathrm{KS}-94-182, \mathrm{C}$ holotype, K, FH isotypes) $\times 0.6$.

Photos: 15, 16 J.H. Petersen. 21 K. Hansen. 14, 17, 18 M. Castellano. 20 T. Læssøe. 13 D.S. Hibbett. 19 D. Luoma.

1996, Dissing 2000), while others have regarded it as a part of Peziza in the sense adopted here (e.g., following Korf 1960, 1972, Le Gal 1953b, 1962). Whether the shape of the spores is a reliable character at the generic level has been a persistent controversy. Other characters have been proposed to support the recognition of Plicaria. These are pale brownish spores, paraphyses embedded in a granular matrix, dark-colored apothecial pigments (brown pigment on the walls of the asci), Chromelosporium anamorphs and a carbonicolous habitat (FIG. 16). Egger (1987) found that Plicaria trachycarpa, $P$. endocarpoides and some species of Peziza (P. atrovinosa, P. ostracoderma, Peziza sp. \#2), exhibited a positive tyrosinase reaction, while other species of Peziza had a negative reaction. Egger noted that if correlating characters were found, the concept of Plicaria might have to be modified to include ellipsoid-spored species as in the orig- inal concept. Moravec and Spooner (1988) reached the same conclusion based on a morphological study of brown-spored species of Peziza ( $P$. atrovinosa, $P$. vacinii, $P$. retiderma Cooke, $P$. rifaii J. Moravec \& Spooner and P. ostracoderma) and stated that if $P(i-$ caria is to be recognized "the inclusion in it of species with non-globose spores appears unavoidable." Phylogenetic analyses by Norman and Egger (1996) including most of these taxa, indicated that the globose-spored Plicaria is monophyletic, but nested within Peziza. They accepted the genus ad interim even though it implied a paraphyletic Peziza. In this study we are using the name Plicaria as emended by Boudier.

Boudiera Cooke (1877) has been placed in the Ascobolaceae (Boudier 1907, Korf 1972, 1973b) due to the turbinate to pulvinate ascomata (FIG. 6), protruding asci and pale brownish spores, but its relationship 
has been much disputed. Eckblad (1968) stated that Boudiera did not seem to be closely related to any other genus with protruding asci, but he, nevertheless, referred it to the Ascobolaceae. Boudiera was revised (Dissing and Schumacher 1979) and placed in the Pezizaceae by Dissing and Korf (1980) and Hirsch (1980) along with other genera with globose spores and amyloid asci. Dissing and Korf emphasized characters of the anatomy and morphology of the ascomata and suggested that Boudiera is in a line with Plicaria on the one hand, and Ruhlandiella and Sphaerozone on the other. Hirsch (1980) considered Boudiera closely related to Plicaria, as did Rifai (1968). Hirsch also pointed out similarities in the excipulum structure, besides spore color, amyloid reactions of asci (which blue evenly over the entire length in both Plicaria and Boudiera) (TABLE I), agglutination of paraphyses and often a complex spore ornamentation. He did not find protruding asci, a consistent generic character in Boudiera. Molecular phylogenetic analyses (Landvik et al 1997, Norman and Egger 1999) support the placement of Boudiera in the Pezizaceae.

Pachyella Boud. (1907) (FIG. 5) was synonymised with Peziza (Donadini 1980b, Eckblad 1968, Seaver 1928), but was accepted by Le Gal (1947, 1953a), Korf (1972) and Pfister (1973) based on the presence of a well-developed cortical zone of globose cells which on the outside terminate in hyaline, hyphoid hairs, embedded in a gel and asci usually diffusely amyloid. Donadini (1980b) gave Pachyella subgeneric rank under Peziza. Most taxonomists have followed Pfister (1973). Hirsch (1984) even regarded Pachyella as so isolated within the Pezizaceae that he proposed a tribus Pachyelleae for this taxon alone, opposed to tribus Pezizeae including all other genera of the family.

Iodophanus Korf (Kimbrough and Korf 1967) was segregated from Ascophanus Boud. (tribus Pseudoascoboleae, Ascobolaceae) and was, along with Thecotheus Boud., assigned to the tribus "Pezizeae" (Pezizaceae) rather than the tribus Theleboleae (Pezizaceae), because they possess amyloid asci, spores with cyanophilic spore markings and an Oedocephalum conidial state (Gamundi and Ranalli 1964). Korf (1972, 1973b) later treated Iodophanus in the Ascobolaceae (tribe Iodophaneae), emphasizing the thick-walled spores in early stages of development, the carotenoid pigments, and asci that protrude prominently at maturity (FIG. 1). Furthermore, Korf stated that the tribe Iodophaneae (Iodophanus, Boudiera, Thecotheus and Sphaerosoma) seems surely to represent the link between Pezizaceae and Ascobolaceae. On the contrary, Iodophanus has been regarded as a "primitive type" within the Pyronemataceae by Eckblad (1968), based on the paraphyses' containing carotenoid pigments, the excipular structure, and the diffusely amyloid type of ascus. A close relationship between Iodophanus, Peziza and Plicaria has been indicated by septal ultrastructure of asci and ascogenous hyphae (Kimbrough and Curry 1985). Two ascal septum types were found; the pezizoid and the ascoboloid. The genus Thecotheus shared the ascoboloid type with Ascobolus and Saccobolus Boud. Molecular phylogenetic studies support the relationship of Iodophanus to the Pezizaceae and of Thecotheus to Ascobolaceae (Landvik et al 1997, 1998).

Scabropezia Dissing \& Pfister (1981) was segregated from Plicaria and Peziza, based on the anatomy of the apothecia. In this genus the outer surface of the ascomata is pustulate (FIG. 7), the pustules being composed of aggregates of globose to angular cells clearly separated from the medullary excipulum of textura intricata. Only two species are known.

Hapsidomyces J.C. Krug \& Jeng (1984) was erected for $H$. venezuelensis Krug \& Jeng and assigned to the Pezizaceae based on the amyloid asci and the thinwalled, pale-colored spores. Krug and Jeng considered it to be closely related to Boudiera (see TABLE I), but sufficiently distinct by its early cleistohymenial development; a distinct apothecial margin; short, narrow asci with a short stipe; a rather narrow operculum; filiform paraphyses with yellowish content; small, eguttulate spores, and a coprophilous habitat. As in Boudiera, the asci protrude at maturity.

Kimbropezia Korf \& Zhuang (1991) was described on the basis of a cyanophilic and Congo Red-staining lens-shaped thickening ("opercular lens") within the ascus operculum. The asci were further noted to be unusually brittle and with rather abruptly narrowed and often twisted bases. The genus was assigned to the Pezizaceae, differing from Peziza only by the very peculiar asci (see TABLE I). Van Brummelen (1998) studied the ascus apical structure by TEM and found it to be unique. He considered Kimbropezia best placed as a rather aberrant genus in the Pezizaceae. On the contrary, molecular analysis by Norman and Egger (1999) placed Kimbropezia within Peziza.

Rhodopeziza Hohmeyer \& Moravec (Moravec 1994) was described for $R$. tuberculata (Gamundí) Moravec \& Hohmeyer (= Aleuria tuberculata Gamundí). It differs from Aleuria in having amyloid asci and tuberculate spores which are not regularly biguttulate. According to Moravec (1994) it has a special position in the Pezizales, with its carotenoid granules in the paraphyses and asci being amyloid over the entire length. It shares characters with Iodophanus in particular, especially the presence of carotenoids, ornamented spores and diffusely amyloid asci. It was 
placed in the Pezizaceae by Eriksson and Hawksworth (1995).

Iodowynnea Medel, Guzmán \& Chacón (Medel et al 1996) was segregated from Peziza based on its large, convoluted to highly folded apothecia, arising from a buried stipe, and longitudinally verrucose-striate spores. One of the authors, Korf, reserved judgement on whether the new taxon should be considered a subgenus of Peziza or merit generic rank. Le Gal (1953a) and Pfister (1974) treated the species in Galactinia and Peziza respectively.

Marcelleina Brumm., Korf \& Rifai (van Brummelen 1967 ) is included in this study to test the hypothesis of a close relationship to Peziza gerardii.

Hypogeous genera. The truffle or truffle-like genera presented below, except for Mycoclelandia and Cazia, were originally described in the order Tuberales (Tuberaceae or Terfeziaceae) due to their hypogeous habit and lack of forcible spore discharge.

Hydnobolites Tul. \& C. Tul. (1843) was described for $H$. cerebriformis Tul. \& C. Tul. It was referred to Tuberaceae by Gilkey (1954b) and Korf (1973b), but placed in the Terfeziaceae by Hawker (1954) and Trappe $(1971,1979)$ because the spores are globose and there is no organized hymenium with paraphyses at any stage of development. This position has been accepted by most subsequent authors. The genus was distinguished from others in the Terfeziaceae by having an interior layer of solid undifferentiated tissue in which the asci are randomly distributed. Meandering veins deeply penetrate the interior of the ascomata from the outer surface. These are lined with outer excipulum tissue. The asci are non-amyloid without pretreatment in $\mathrm{KOH}$, therefore Hydnobolites was not placed in the Pezizaceae. Trappe (1979) regarded Hydnobolites to be close to both Pachyphloeus and Terfezia. The recent discovery of several cytological and ultrastructural features by Kimbrough et al (1991) made them suggest that Hydnobolites belongs in Pezizaceae. These features are the electron-dense, biconvex bands in septal pores of the asci, dextrinoid and weakly amyloid asci (only after pretreatment with $2 \% \mathrm{KOH}$ ) and a type of spore wall deposition similar to members of Pezizaceae.

Pachyphloeus Tul \& C. Tul. (1844) was erected for P. melanoxanthus (Tul.) Tul \& C. Tul. It was, like Hydnobolites, referred to Tuberaceae by Gilkey (1954b) and Korf (1973b), and placed in the Terfeziaceae by Trappe (1979). Hawker (1954) placed the genus in Eutuberaceae E. Fisch. It lacks a hymenium and asci irregularly line veins or are randomly produced in the medullary excipulum. An apical depression or pore leading into a few open veins is characteristic of the ascomata. The verrucose outer excipulum of isodiametric cells separates Pachyphloeus and Hydno- bolites from other genera of the Terfeziaceae (Trappe 1979). However, amyloid asci occur in some species of Pachyphloeus (e.g., in the type species), and based on this and anatomical features, the genus has been placed in the Pezizaceae by Dissing and Korf (1980) and Dissing (2000). Molecular phylogenetic analyses has recently confirmed this placement (Norman and Egger 1999, Percudani et al 1999).

Terfezia (Tul. \& C. Tul.) Tul. \& C. Tul. (1851) was elevated from Choiromyces section Terfezia Tul. \& C. Tul. to generic rank. It was distinguished by having pockets of fertile tissue separated by sterile, but otherwise undifferentiated veins, highly ornamented spores and non-amyloid asci (Trappe 1971, 1979). It is the type genus of Terfeziaceae, and the most heterogeneous genus of the family. Recent molecular phylogenetic analyses suggest that Terfezia is not monophyletic, and that it is nested within Pezizaceae (Norman and Egger 1999, Percudani et al 1999).

Sphaerozone Zobel (Corda 1854) was described for S. tulasnei Zobel (= Sphaerosoma ostiolatum Tul. \& C. Tul.), which has reddish brown spores. Dissing and Korf (1980) studied the type species and discovered that the asci are amyloid, contrary to previous reports by Korf $(1972,1973 b)$. Under the impression that asci were non-amyloid Korf treated the genus in Pyronemataceae, rather than a genus in Pezizaceae as was subsequently done by Dissing and Korf (1980). It differs from Ruhlandiella by having paraphyses without gelatinous sheaths and persistent asci.

Tirmania Chatin (1891) was described for T. africana Chatin (= Tuber niveum Desf.). It was placed in the Terfeziaceae by Trappe (1971) and Korf (1973b). It resembles Terfezia, but differs by having smooth or at most minutely roughened spores and amyloid asci. Based on the amyloid reaction and its anatomy, Trappe (1979) transferred the genus to the Pezizaceae.

Ruhlandiella Henn. (1903) was redescribed and emended by Dissing and Korf (1980), who selected a neotype for the type species $R$. berolinensis. They found the asci to be amyloid and the paraphyses to have characteristic gelatinous sheaths (features not mentioned in Hennings' original description). The ascomata are relatively small, hypogeous or semi-hypogeous, solid, pulvinate to globose ascomata and with the hymenium covering the outer surface and permanently exposed (FIG. 19) (Dissing and Korf 1980, Galán and Moreno 1998, Warcup and Talbot 1989 as Muciturbo Talbot). Asci are evanescent at maturity. Dissing and Korf (1980) referred Ruhlandiella to the Pezizaceae, with other globose-spored, amyloid genera. A close relationship to Sphaerozone, in a lineage with Boudiera and Plicaria, was suggested.

Hydnotryopsis Gilkey (1916) was erected for $H$. setchellii, but later synonymized with the globose- 
spored Choiromyces Vittad. (Tuberaceae) (Gilkey 1954b). Trappe (1975a), however, showed that it has amyloid asci and, based on this and its ellipsoid spores, the genus was reinstated. Fischer (1938) and Trappe (1979) placed the genus in the Pezizaceae. The ascomata are solid, but the asci and paraphyses are arranged in hymenia.

Amylascus Trappe (1971) (FIG. 8) was segregated from Hydnobolites on the basis of its thick-walled, amyloid asci, echinulate spores and the verrucose outer excipulum of large inflated cells which gives rise to a tomentose outer surface (Trappe 1971, 1975b, Beaton and Weste 1982). It was described in the Terfeziaceae for a single species, $H$. herbertianus Cribb. Later, Trappe (1975b) considered the genus to be closely related to the Geneaceae in both form and anatomy, and the similarities between Hydnobolites and Amylascus to be the result of parallel evolution. When restricting Terfeziaceae to include only genera with non-amyloid asci, however, Trappe (1979) transferred Amylascus to Pezizaceae.

Mycoclelandia Trappe \& Beaton (1984) was proposed to replaced Clelandia Trappe (1979), a homonym of Clelandia J.M. Black (Violaceae). It was placed in the Pezizaceae, and noted to resemble $P e^{-}$ $z i z a$ s.l. in several anatomical features, but differing in its "cleistothecial" ascomata and indehiscent asci (Trappe 1979). The asci are diffusely amyloid with the reaction strongest near the apex.

Cazia Trappe (1989) was assigned initially to the Helvellaceae due to the non-amyloid asci and large isodiametric cells in the excipulum. It differed from other similar hypogeous genera by its hyaline, minutely ornamented spores, crooked asci and a yellow $\mathrm{KOH}$ reaction of the fresh medullary excipulum. The genus was identified as a member of the Pezizaceae, using sequences from the nLSU and nSSU rDNA (O’Donnell et al 1997).

\section{MATERIALS AND METHODS}

Material studied.-Forty eight collections of Peziza representing 39 species were selected to cover the range of macro- and micromorphological characters, and habitats and substrates recognized within the genus. To critically assess the monophyly of Peziza and define its sistergroup relationships, representatives of the genera Amylascus, Boudiera, Hydnotryopsis, Iodowynnea, Pachyella, Ruhlandiella and Tirmania were included (Tables I, II). For a few selected species more than one collection was sequenced to verify the LSU rDNA sequences and estimate the intraspecific variation. LSU rDNA sequences from 12 additional species of Peziza and representatives of the genera Cazia, Iodophanus, Kimbropezia, Plicaria, Sarcosphaera and Scabropezia were obtained from GenBank (TABLE II). To assess the monophyly of the Pezizaceae and the relationship to the genera Mar- celleina and Pfistera Korf \& W.Y. Zhuang (currently placed in the Pyronemataceae), species belonging to the Ascobolaceae (Ascobolus), Morchellaceae (Verpa Fr.) and Pyronemataceae (Aleurina Massee, Otidea (Pers.) Bonord., Smardaea Svrček) were included. Generic type species were used as far as possible (TABLE II). Neolecta vitellina was used to root the tree because phylogenetic analyses at more inclusive levels places Neolecta Speg. basal to the rest of the fruitbody producing ascomycetes and the budding yeasts (Landvik et al 1993, Landvik 1996). To test the influence of the outgroup on the analyses, Neolecta was replaced with Orbilia Fr., which has been suggested as the sister group to the Pezizales (Harrington et al 1999, Platt and Spatafora 2000).

Several collections of most included Peziza species have been studied morphologically, and existing types or other original material have been examined. The amyloid reactions of asci have been examined in additional specimens of other included genera. A list of the specimens is available from KH. The published voucher specimen for Pachyella clypeata (ALTA 9029, GenBank SSU: AF133144, LSU: U40619) (Norman and Egger 1999) was examined by $\mathrm{KH}$ and DHP and was redetermined as Peziza subisabellina. The voucher specimens for the other sequences obtained from GenBank have not been studied morphologically by us.

Morphological methods. - The voucher material was studied using light microscopy, and was identified or identifications were verified by KH. All species of Pachyella were further confirmed by DHP. Special notice was paid to the intensity and location of the amyloid reaction in asci by using Melzer's reagent ( $1.5 \mathrm{~g}$ iodine, $5.0 \mathrm{~g}$ potassium iodide, $100 \mathrm{~g}$ chloral hydrate, $100 \mathrm{~mL}$ distilled water), applied with or without $\mathrm{KOH}$ pretreatment $(2 \%$ or $10 \% \mathrm{KOH})$. Other chemicals used were Cotton Blue in lactic acid ( $1 \%$ in 875 mL lactic acid, $63 \mathrm{~mL}$ glycerol, $62 \mathrm{~mL}$ water) and Congo Red in ammonia $(0.3 \%$ in commercial ammonia cleaner). For critical species the spore surface was viewed by an AMRay 1000 scanning electron microscope (SEM). The anatomical structures of the excipulum were studied using hand sections (for fresh material) or sections made on a freezing microtome. Microanatomical terminology follows Korf (1973b). Photographs of the ascus amyloid reactions were made with an Olympus $\mathrm{BH} 2$ microscope and an Olympus C35AD-4 camera, and processed in Photoshop (Adobe Photoshop 4.0).

Molecular methods.-DNA was isolated from dried or fresh ascomata and was extracted as outlined in Hansen et al (1999). Serial dilutions of DNA $(1: 10,1: 100,1: 1000)$ were used as template for the polymerase chain reaction (PCR). The $5^{\prime}$ end of the nuclear large subunit rDNA (nLSUrDNA), spanning domains D1 and D2, was amplified using the primers LROR and LR5 (for a few taxa LR5 was replaced with LR3 or LR7) (Moncalvo et al 2000). PCR products were purified either directly or following agarose gel electrophoresis and band excision using QIAquick spin columns (Qiagen 1997). In addition to the primers used for PCR, internal primers PNL2 (O'Donnell et al 1997) and LSU0354-5' (5' - GCA AGA GAC CGA TAG CGC ACA AGT $\left.\mathrm{AG}-3^{\prime}\right)$ designed for Peziza, were used for BigDye terminator cycle sequencing (Applied Biosystems, Foster City, 
California) following the manufacturer's protocol, except that reaction volumes were $10 \mu \mathrm{L}$. Sequencing reactions were purified using ethanol/sodium precipitation (ABI protocol). Sequencing reactions were electrophoresed and data collected on an Applied Biosystems 377 automated DNA sequencer (Perkin-Elmer/ABI).

Analytical methods.--Sequences were edited and contigs assembled using Sequencher 3.0 (GeneCodes, Ann Arbor, Michigan). Sequences are deposited in GenBank (TABLE II). Nucleotide sequences were aligned manually in the data editor of PAUP*4.0b3a (Swofford 1998) with alignment gaps inserted to optimize aligned sites. The data matrix is available from TreeBASE (http://phylogeny.harvard.edu/ treebase) as accessions S612 and M947. Nucleotide diversity (e.g., Nei 1987, equation 10.6), as the average number of nucleotide differences per site between two LSU rDNA sequences, were calculacted within and between selected species.

Phylogenetic analyses were performed in PAUP*4.0b3a (Swofford 1998) on an iMac $350 \mathrm{MHz}$ (unless otherwise stated). Maximum parsimony (MP) analyses with heuristic searches were performed, with 1000 random stepwise addition replicates and TBR branch swapping. All characters were equally weighted and unordered. Gapped positions were included, treated as missing data (gap = missing), or excluded in separate analyses. A two-step search was performed based on strategies designed by Maddison et al (1992) and Olmstead et al (1993): first, only up to two trees per replicate were kept, then exhaustive swapping was performed on all of the most parsimonious trees discovered, with MAXTREES set to 15000 . Relative robustness of individual branches was estimated by bootstrap, using 500 replicates, with heuristic searches, 10 random addition sequences, TBR branch swapping and MAXTREES set at 100 .

Maximum likelihood (ML) analyses were performed using two different starting trees for TBR branch swapping: one of the most parsimonious trees and a tree generated with one random taxon addition sequence. Empirical nucleotide frequencies were used, with the Felsenstein (1984) two-parameter model for unequal base frequencies. The proportion of invariable sites was set to zero and an equal rate of substitution was assumed for all sites. The starting parameter values were obtained using the Rogers-Swofford method (Swofford 1998). To find the optimal tree, searches were repeated by varying the transition:transversion ratio until the best ML score was reached. Due to the large number of taxa, ML bootstrap values were generated using a "fast" stepwise sequence addition, with 100 replicates and a transition:transversion ratio of 1.9:1 (the optimal value from the previous analyses). This method does not optimize trees by swapping branches (Swofford 1998) and is therefore fast but not thorough. Equal bootstrap values $( \pm 5 \%$ ) were obtained with ML analysis using fastDNAml V. 1.0.8 (Olsen et al 1994), with 100 replicates. The latter analysis however, required a 14-d search on a Pentium $600 \mathrm{MHz}$ computer, whereas the "fast" bootstrapping was conducted on an iMac $350 \mathrm{MHz}$ in $6 \mathrm{~d}$.

MacClade 3.04 (Maddison and Maddison 1992) was used to infer historical patterns of transformation between an epigeous and a hypogeous habit, with equally-weighted transformations. Topologically constrained parsimony analyses were used to evaluate the hypothesis that all hypogeous Pezizaceae have been derived (repeatedly) from epigeous taxa, with loss of forcible spore discharge. MacClade was used to construct constraint trees. Parsimony analyses were performed under the constraints, using the same settings as specified above, but with MAXTREES set to only 400 in the second step of the search. The Kishino-Hasegawa test (Kishino and Hasegawa 1989) was used to compare 400 trees under the constrained and unconstrained topologies in PAUP 4.0b3a. Maximum likelihood analyses were also performed under the constraints (with a transition:transversion ratio of 1.9:1) and compared to the optimal ML tree.

\section{RESULTS}

Alignment.-The dataset consisted of partial LSU rDNA sequences from 90 specimens. Sixty-eight new sequences were determined in this study. For most specimens, a 900 bp region at the $5^{\prime}$ end of the LSU rDNA was sequenced on both strands. For eight species of Peziza ( $P$. cerea, $P$. depressa, P. granulosa, $P$. proteana, $P$. saniosa, $P$. subviolacea, $P$. succosella and Peziza sp. 1) only a c $620-680$ bp. region at the $5^{\prime}$ end was determined. Sequences obtained from GenBank (27 specimens) were likewise c 620 bp. Missing data were spaced out with gaps in the alignment, and these positions were therefore either treated as missing data or excluded from analyses. The aligned length of all sequences including inserted gaps was $966 \mathrm{bp}$. The missing data could have introduced error in the phylogenetic estimates (Maddison 1993, Wiens 1998), however analyses of only the 620 bp region for the full dataset resulted in the same basic topologies and bootstrap values, with only slightly fewer resolved nodes.

No size variability due to introns was observed. LSU rDNA sequences from the same morphological species showed either no (e.g., $P$. depressa, $P$. echinispora) or several substitutions or deletions (e.g., $P$. gerardii, P. subisabellina, Pachyella babingtonii). Intraspecific genetic variation was in some cases larger than interspecific variation, e.g., the nucleotide diversity within $P$. gerardii was $3.1 \%$ and within Pachyella babingtonii $1.7 \%$, whereas the average nucleotide diversity between the Peziza species within group IVa was only $1.3 \%$. Identical sequences of the same morphological species were left out of the analyses.

Phylogenetic analyses.-Under gap = missing coding there were 319 parsimony informative characters. With gapped positions omitted this number decreased to 249. Maximum parsimony analysis produced over 15000 equally most parsimonious trees 
TABLE II. List of species used in the molecular phylogenetic study, with voucher specimen information and GenBank accession numbers. Information on new sequences are listed first, followed by information on sequences obtained from GenBank. Numbers in parentheses are used to indicate multiple collections of a single taxon.

\begin{tabular}{|c|c|c|c|}
\hline Species & Voucher and geographic origin & Year and collector & GenBank \\
\hline Nov. gen. ? & T. Laessøe 6236 (C). Malaysia & 1999, T. Laessøe & AF335111 \\
\hline $\begin{array}{l}\text { Aleurina imaii (Korf) W.Y. } \\
\text { Zhuang \& Korf }\end{array}$ & CUP-CH 2333 (CUP). China & 1981, R-y. Zheng, R.P. Korf & AF335112 \\
\hline $\begin{array}{l}\text { Amylascus tasmanicus (Rodway) } \\
\text { Trappe }\end{array}$ & $\begin{array}{l}\text { Trappe } 18084 \text { (C, dubl. OSC). } \\
\text { Australia }\end{array}$ & 1996, J. Trappe & AF335113 \\
\hline $\begin{array}{l}\text { Boudiera dennisii Dissing \& Sivert- } \\
\text { sen }\end{array}$ & HK $90.074(C)$. Russia & 1990, H. Knudsen & AF335114 \\
\hline Hydnotryopsis setchellii Gilkey ${ }^{\mathrm{a}}$ & $\begin{array}{l}\text { Trappe } 19134 \text { (C, dubl. OSC). } \\
\text { USA }\end{array}$ & 1996, J. Trappe & AF335115 \\
\hline Hydnotryopsis sp. & $\begin{array}{l}\text { Trappe } 17231 \text { (C, dubl. OSC). } \\
\text { USA }\end{array}$ & 1995, J. Trappe & AF335116 \\
\hline $\begin{array}{l}\text { Iodowynnea auriformus (Le Gal) } \\
\text { Medel, Guzmán \& Chacón }{ }^{\text {a }}(1)\end{array}$ & CUP-ME566 (CUP). Mexico & 1986, Ramón-Farias & AF335117 \\
\hline Iodowynnea auriformis (2) & 18510 PAN $(\mathrm{FH})$. India & 1981, R. Kaushal & AF335118 \\
\hline $\begin{array}{l}\text { Marcelleina persoonii (P. Crouan \& } \\
\text { H. Crouan) Brumm. }{ }^{\text {a }}\end{array}$ & HD S85-96 (C). Svalbard & 1985, H. Dissing & AF335119 \\
\hline $\begin{array}{l}\text { Marcelleina tuberculispora K. Han- } \\
\text { sen \& Sandal }\end{array}$ & All-94-8 (C, type). Denmark & 1994, K. Hansen, S.K. Sandal & AF335120 \\
\hline Otidea onotica (Pers.: Fr.) Fuckel ${ }^{\mathrm{a}}$ & KH-98-107 (C). Denmark & 1998, K. Hansen & AF335121 \\
\hline $\begin{array}{l}\text { Pachyella babingtonii (Berk. \& } \\
\text { Broome) Boud. (1) }\end{array}$ & KS-94-45 (C). Denmark & 1994, K. Hansen, S.K. Sandal & AF335122 \\
\hline Pachyella babingtonii (2) & KH-99-09 (C). USA & 1999, K. Hansen, D.H. Pfister & AF335123 \\
\hline Pachyella punctispora Pfister & KH-98-77 (C). Austria & 1998, K. Hansen & AF335124 \\
\hline $\begin{array}{l}\text { Pachyella violaceonigra }(\text { Rehm }) \\
\text { Pfister }^{\mathrm{a}}\end{array}$ & s.n. (FH). Switzerland & 1979, A. Nyffenegger & AF335125 \\
\hline Peziza ammophila Durieu \& Mont. & SAE-1245 (C). Denmark & 1984, S.A. Elborne & AF335126 \\
\hline Peziza ampelina Quél. & KH $00.011(\mathrm{C})$. Denmark & 1994, C. Lange & AF335127 \\
\hline Peziza ampliata Pers.: Fr. & JHC 92-386 (C). Denmark & 1992, J. Heilmann-Clausen & AF335128 \\
\hline Peziza apiculata Cooke & $\begin{array}{l}\text { Winterhoff } 86239 \text { (herb. Win- } \\
\text { terhoff). Germany }\end{array}$ & 1986, W. Winterhoff & AF335129 \\
\hline $\begin{array}{l}\text { Peziza arvernensis Roze \& Boud. } \\
\text { (1) }\end{array}$ & KH-98-08 (C). Denmark & 1998, A. Storgaard & AF335130 \\
\hline Peziza arvernensis $(2)$ & KH-98-12 (C). Denmark & 1998, B. Klug-Andersen & AF335131 \\
\hline Peziza badiofusca (Boud.) Dennis & KH-98-113 (C). Sweden & 1992, S.-Å. Hanson & AF335132 \\
\hline Peziza bananicola (Rehm) Sacc. & $\begin{array}{l}\text { V. Demoulin } 5529(\mathrm{FH}) \text {. New } \\
\text { Guinea }\end{array}$ & 1979, V. Demoulin, L. Smeets & AF335133 \\
\hline Peziza cerea Bull.: Fr. & KH-97-54 (C). Denmark & 1997, J.H. Petersen & AF335134 \\
\hline Peziza depressa Pers. (1) & KH-98-28 (C). Denmark & 1998, H. Knudsen & AF335135 \\
\hline Peziza depressa (2) & KH-98-18 (C). Denmark & 1998, K. Hansen, T. Læssøc & AF335136 \\
\hline Peziza domiciliana Cooke & C no. 52152 (C). Denmark & 1989, P.M. Petersen & AF335137 \\
\hline Peziza echinispora P. Karst (1) & $\begin{array}{l}\text { Jukka Vauras } 9110 \mathrm{~F} \text { (TURA). } \\
\text { Finland }\end{array}$ & $1994, \mathrm{~J}$. Vauras & AF335138 \\
\hline Peziza ellipsospora (Gilkey) Trappe & $\begin{array}{l}\text { Trappe } 13017 \text { (C, dubl. OSC). } \\
\text { USA }\end{array}$ & 1993, J. Trappe & AF335139 \\
\hline Peziza emileia Cooke & $\begin{array}{l}\text { Brummelen } 1921 \text { (L) The } \\
\text { Netherlands }\end{array}$ & 1994, G. Piepenbroek-Groters & AF335140 \\
\hline $\begin{array}{l}\text { Peziza exogelatinosa } \mathrm{K} \text {. Hansen \& } \\
\quad \text { Sandal }\end{array}$ & $\begin{array}{l}\text { KS-94-149 (C, dubl. FH) Den- } \\
\text { mark }\end{array}$ & 1994, K. Hansen, S. K. Sandal & AF335141 \\
\hline Peziza gerardii Cooke (1) & KH-98-86 (C). Denmark & 1998, K. Hansen & AF335142 \\
\hline Peziza gerardii $(2)$ & KH-97-90 (C). Denmark & $\begin{array}{l}\text { 1997, M. Christensen, K. Han- } \\
\text { sen }\end{array}$ & AF335143 \\
\hline Peziza gerardii $(3)$ & KH-98-42 (C). Denmark & 1998, T. Læssøe, K. Hansen & AF335144 \\
\hline Peziza granulosa Schumach. & KH 00.012 (C). Denmark & 1994, K. Hansen, S.K. Sandal & AF335145 \\
\hline Peziza howsei Boud. & KH-97-98 (C). Denmark & 1997, J.H. Petersen, C. Lange & AF335146 \\
\hline
\end{tabular}


TABle II. Continued

\begin{tabular}{|c|c|c|c|}
\hline Species & Voucher and geographic origin & Year and collector & GenBank \\
\hline Peziza limnaea Maas Geest. & HFG $94.2(\mathrm{C})$. Denmark & 1994, H.F. Gøtzsche & AF335147 \\
\hline Peziza luteoloflavida Svček & $\begin{array}{l}\text { T. Schumacher \& K. Østmoe D } \\
170 / 83(\mathrm{O}) \text {. Norway }\end{array}$ & 1983, T. Schumacher, K. Østmoe & AF335148 \\
\hline Peziza michelii (Boud.) Dennis & KH-98-13 (C). Denmark & 1998, T. Laessøe & AF335149 \\
\hline Peziza micropus Pers.: Fr. (1) & KH-97-107 (C). Denmark & 1997, K. Hansen & AF335150 \\
\hline Peziza micropus (2) & KH-99-04 (C). USA & 1999, Z. Yang & AF335151 \\
\hline Peziza natrophila A.Z.M. Khan (1) & $\begin{array}{l}\text { Kew } 59522 \text { (K, Isotype). Bang- } \\
\text { ladesh }\end{array}$ & 1970, G.B. Hants et al. & AF335152 \\
\hline Peziza natrophila (2) & JHP 93.021 (C). Denmark & 1993, J. Vesterholt et al. & AF335153 \\
\hline $\begin{array}{l}\text { Peziza nivalis (Hein \& Remy) } \\
\text { M.M. Moser }\end{array}$ & KH-97-44 (C). USA & 1997, K. Hansen & AF335154 \\
\hline Peziza phyllogena Cooke (1) & KH-99-03 (C). USA & 1999, K. Hansen, D.H. Pfister & AF335155 \\
\hline Peziza phyllogena $(2)$ & $\begin{array}{l}\text { s.n. (TUR, type of Peziza kal- } \\
\text { lioi). Finland }\end{array}$ & 1965, K. Mäkinen & AF335156 \\
\hline $\begin{array}{l}\text { Peziza polaripapulata (J. Moravec) } \\
\text { K. Hansen }\end{array}$ & KS-95-10A (C). Denmark & 1995, H. Knudsen, M. Sasa & AF335157 \\
\hline $\begin{array}{l}\text { Peziza proteana (Broud). Seaver } \mathrm{f} . \\
\quad \text { proteana }\end{array}$ & Ginns $4156(\mathrm{FH})$. Canada & 1997, J. Ginns & AF335158 \\
\hline $\begin{array}{l}\text { Peziza retrocurvata } \mathrm{K} \text {. Hansen \& } \\
\text { Sandal }\end{array}$ & KS-94-182 (C). Denmark & 1994, K. Hansen, S.K. Sandal & AF335159 \\
\hline Peziza saniosa Schrad.: Fr. & KH-97-137 (C). Denmark & 1997, C. Lange & AF335160 \\
\hline Peziza subcutrina (Bres.) Koif (1) & KS-94-133 (C). Denmark & 1994, K. Hansen, S.K. Sandal & AF335161 \\
\hline Peziza subcitrina (2) & KH-97-133 (C). Denmark & 1997, C. Lange, K. Hansen & AF335162 \\
\hline $\begin{array}{l}\text { Peziza subisabellina (Le Gal) } \\
\text { Blank, Haffner \& Hohmeyer } \\
\text { (1) }\end{array}$ & $\begin{array}{l}\text { RK } 96.54 \text { (herb. Roy Kristian- } \\
\text { sen). Norway }\end{array}$ & 1996, R. Kristiansen & AF335163 \\
\hline Peziza subisabellina $(2)$ & $\begin{array}{l}\text { Winterhoff } 8844 \text { (herb. Winter- } \\
\text { hoff.). Germany }\end{array}$ & 1988, W. Winterhoff & AF335164 \\
\hline Peziza subviolacea Svrček (1) & KH-98-29 (C). Denmark & 1998, B. Klug-Andersen & AF335165 \\
\hline Peziza succosa Berk. & KH-98-07 (C). Denmark & 1998, A. Storgaard & AF335166 \\
\hline $\begin{array}{l}\text { Peziza succosella (Le Gal \& Rom- } \\
\text { agn.) Aviz.-Hersh. \& Nemlich }\end{array}$ & KH-97-139 (C). Denmark & 1997, C. Lange & AF335167 \\
\hline Peziza whitei (Gilkey) Trappe & $\begin{array}{l}\text { Trappe } 17049 \text { (C, dubl. OSC). } \\
\text { Australia }\end{array}$ & 1995, J. Trappe & AF335168 \\
\hline Peziza sp. 1 & KH-98-30 (C). Denmark & 1998, K. Hansen & AF335169 \\
\hline Peziza sp. 2 & C. no. 52153 (C). Denmark & 1982, S.A. Elborne, H. Knudsen & AF335170 \\
\hline Peziza sp. 3 & $\begin{array}{l}\text { PM-120-97 (Herb. Roy Kristian- } \\
\text { sen). Norway }\end{array}$ & 1997, P. Marstad & AF335171 \\
\hline Peziza sp. 4 & KH-97-85 (C). Denmark & 1985, J.H. Petersen, K. Hansen & AF335172 \\
\hline Peziza sp. 5 & HD S.85.41 (C). Svalbard & 1985, H. Dissing & AF335173 \\
\hline $\begin{array}{l}\text { Pfistera pyrophila Korf \& W.Y. } \\
\text { Zhuanga }\end{array}$ & $\begin{array}{l}\text { CUP-MM } 854 \text { (CUP, type). Ca- } \\
\text { nary Islands }\end{array}$ & 1976, R.P. Korf et al. & AF335174 \\
\hline Ruhlandiella berolinensis Henn. ${ }^{\mathrm{a}}$ & $\begin{array}{l}\text { Mycoflora of Macaronesia } 1230 \\
\text { (C, isoneotype). Canary Is- } \\
\text { lands }\end{array}$ & 1976, R.P. Korf et al. & AF335175 \\
\hline $\begin{array}{l}\text { Smardaea amethystina (W. Phil- } \\
\text { lips) Svrček }\end{array}$ & KH-97-132 (C). Denmark & 1997, C. Lange, K. Hansen & AF335176 \\
\hline $\begin{array}{l}\text { Tirmania nivea (Desf.: Fr) Trap- } \\
\text { pe }^{\mathrm{a}}\end{array}$ & $\begin{array}{l}\text { Trappe } 23190(\mathrm{C}, \text { dubl. OSC). } \\
\text { Israel }\end{array}$ & 1983, C.H. de Vries & AF335177 \\
\hline $\begin{array}{l}\text { Tirmania pinoyi (Maire) Malen- } \\
\text { çon }\end{array}$ & $\begin{array}{l}\text { Trappe } 13587 \text { (C, dubl. OSC). } \\
\text { Saudi Arabia }\end{array}$ & 1982, H. Bakhary & AF335178 \\
\hline \multicolumn{4}{|l|}{ Published sequences: } \\
\hline Ascobolus lineolatus Brumm. & NRRL A23604 & Unknown & AF133159 \\
\hline Cazia flexiascus Trappe ${ }^{\mathrm{a}}$ & JMT 12993 & USA & U42694 \\
\hline Glischroderma sp. & CUP62651 & USA & AF 133160 \\
\hline Iodophanus carneus (Pers.) Korfa & ARON 2102 & Norway & AF 133161 \\
\hline
\end{tabular}


TABLE II. Continued

\begin{tabular}{|c|c|c|c|}
\hline Species & Voucher and geographic origin & Year and collector & GenBank \\
\hline $\begin{array}{l}\text { Kimbropezia campestris Korf \& W.Y. } \\
\text { Zhuanga }\end{array}$ & CUP MM 2761 & Canary Islands & AF133163 \\
\hline $\begin{array}{l}\text { Neolecta vitellina (Bres.) Korf \& } \\
\text { J.K. Rogers }\end{array}$ & NSW 6359 & USA & U42695 \\
\hline Peziza alaskana Cash & ALTA 8477 & Canada & $\mathrm{U} 40615$ \\
\hline Peziza atrovinosa Cooke & DAOM 199606 & USA & $\mathrm{U} 40613$ \\
\hline Peziza badia Pers. (1) & KNE 2205 & Canada & $\mathrm{U} 40614$ \\
\hline Peziza badia (2) & UC 1475104 & Sweden & U42692 \\
\hline Peziza aff. brunneoatra Desm. & KNE 2143 & Canada & $\mathrm{U} 40617$ \\
\hline Peziza echinispora (2) & DAOM 199749 & Canada & AF133165 \\
\hline $\begin{array}{l}\text { Peziza fimeti (Fuckel) E.C. Hans- } \\
\text { en }^{c}\end{array}$ & ALTA 9066 & Canada & AF133170 \\
\hline Peziza griseorosea Gerard & CUP 62472 & USA & U40616 \\
\hline $\begin{array}{l}\text { Peziza lobulata (Velen.) Svček (as } \\
\text { P. violacea } \text { Pers. ss. Dennis } \\
\text { 1978) }\end{array}$ & DAOM 199673 & Canada & AF133171 \\
\hline Peziza aff. merdae Donadini & CUP RPK-206 & USA & AF133166 \\
\hline Peziza ostracoderma Korf & DAOM 199608 & Canada & U40612 \\
\hline Peziza petersii Berk. & DAOM 195796 & Canada & AF133167 \\
\hline $\begin{array}{l}\text { Peziza quelepidotia Korf \& } \\
\text { O'Donnell }\end{array}$ & NRRL 22205 & USA & U42693 \\
\hline Peziza subisabellina $(3)^{\mathrm{b}}$ & ALTA9029 & Canada & U40619 \\
\hline $\begin{array}{l}\text { Peziza subviolacea (2) (as P. prater- } \\
\quad \text { visa Bres. ss Dennis 1978) }\end{array}$ & DAOM 195816 & Canada & $\mathrm{U} 40618$ \\
\hline Peziza vacinii (Velen.) Svrček & NSW 6752 & USA & U40611 \\
\hline $\begin{array}{l}\text { Plicaria acanthodictya Dissing \& } \\
\text { Hauerbach }\end{array}$ & C $530(\mathrm{C})$ & Denmark & U40607 \\
\hline $\begin{array}{l}\text { Plicaria carbonaria } \text { (Fuckel) } \\
\text { Fuckel }\end{array}$ & $20 . \times .1986(\mathrm{C})$ & Denmark & U40608 \\
\hline Plicaria endocarpoides (Berk.) Rifai & DAOM 199089 & Canada & $\mathrm{U} 40610$ \\
\hline Plicaria trachycarpa (Curr.) Boud. ${ }^{a}$ & DAOM 195830 & Canada & U40609 \\
\hline $\begin{array}{l}\text { Sarcosphaera coronaria (Jacq.) } \\
\text { Boud. }{ }^{\mathrm{a}}\end{array}$ & ALTA 9605 & Canada & AF133172 \\
\hline $\begin{array}{l}\text { Scabropezia scabrosa (Cooke) Dis- } \\
\text { sing \& Pfister }\end{array}$ & Pfister 13.8.83 (FH) & USA & AF133173 \\
\hline Verpa bohemica (Krombh.) Schröt. & NRRL $20858=$ CBS 551.72 & Germany & $\mathrm{U} 42672$ \\
\hline
\end{tabular}

a Generic type species.

b Published as Pachyella clypeata (Schw.) Le Gal (Norman \& Egger 1996, 1999).

c Published as Peziza vesiculosa Bull. (Norman \& Egger 1999).

$($ MPT $)$ of 1832 steps under gap $=$ missing coding (consistency index $[\mathrm{CI}]=0.362$, retention index $[R I]=0.650)$, and 1366 steps with gapped positions omitted $([\mathrm{CI}]=0.354,[\mathrm{RI}]=0.658)$. Although the degree of resolution varied in parts of the trees, no conflict between the strict consensus trees of the two sets of analyses was observed (FIG. 23, trees with gapped positions excluded are not shown). Trees obtained in analyses with Orbilia as the outgroup (data not shown) were identical to trees obtained with $\mathrm{Neo}$ lecta as the outgroup. The large number of equally parsimonious trees reflects the inability of the data to resolve the higher order relationships, and relationships between closely related species (FIG. 23).
However, 7 clades were identified (groups I-VII) that were generally well supported (as measured by bootstrapping) or present in all trees (FIGS. 22-23). The Pezizaceae was suggested to be paraphyletic (bootstrap MPT 98\%, ML 94\%), because Marcelleina was nested within it (FIGs. 22-24). Ascobolaceae (represented by Ascobolus under this sampling) was confirmed to be its sister group. The included, currently accepted genera in the Pezizaceae (TABLE I) were all nested within Peziza, with Iodophanus (FIG. 1) in a basal position, either as the sister group to the rest of the Pezizaceae or nested within the Pezizaceae. Peziza gerardii, which forms a clade with Marcelleina (Figs. 2-3) (bootstrap 96\%), is the sister group to 


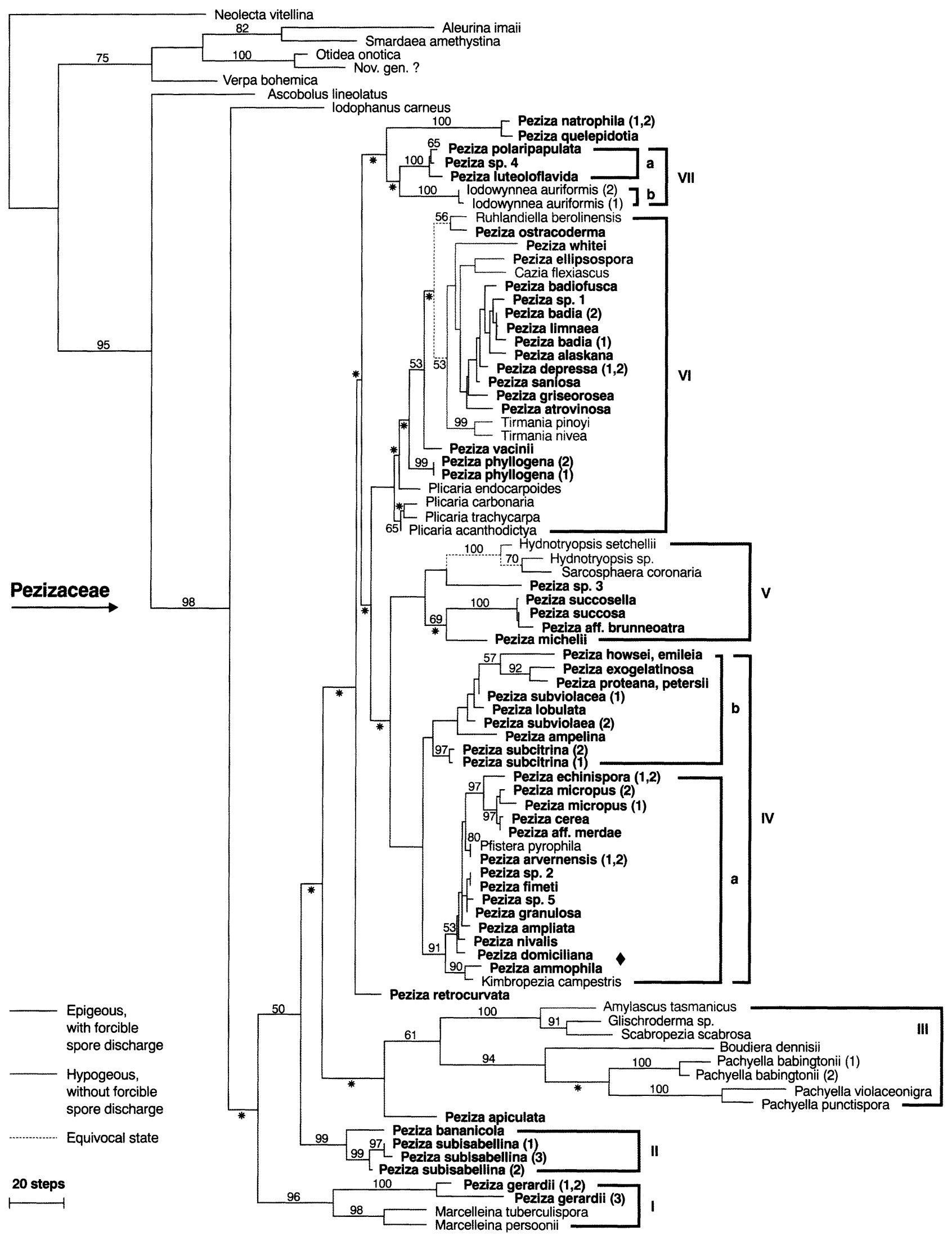


the rest of the Pezizaceae in the MLT (FIG. 24). In the strict consensus of the MPTs, the basal node of the Pezizaceae is unresolved, with Iodophanus, the clade of $P$. gerardii and Marcelleina, and the rest forming a trichotomy (FIG. 23). Species of Peziza occurred in all groups except group III, often along with other genera of the Pezizaceae. Several taxa constitute separate lineages of uncertain placement: $P$. apiculata, $P$. retrocurvata (FIG. 21), and the clade of $P$. natrophila and P. quelepidotia (Figs. 22, 23).

The optimal MLT's found under the two sets of analyses using different starting trees do not have significantly different likelihood scores (Kishino-Hasegawa test, $P<0.05$ ). The optimal MLT was found with a log likelihood score of -11308.898 , under a transition:transversion ratio of 1.9:1 (FIG. 24), with the starting tree generated with one random taxon addition sequence. In analyses with one of the most parsimonious trees as starting tree for branch swapping, the optimal MLT was found with a log likelihood score of -11312.599 , under a transition:transversion ratio of 2.0:1. The ML analyses recovered the groupings found by the MP analyses, with some minor changes. Deeper nodes in the MLT were resolved, but not strongly supported by bootstrapping (FIG. 24), and correspond to those branches that collapse in the strict consensus tree of the MPT's (FIG. 23).

Amyloid reaction types.-Distinct types of ascus amyloid reactions were found to correspond to different rDNA lineages (FIG. 24). The location and intensity of the amyloid reaction are constant in a given species, but varies between species. Four types of reactions were identified: (i) faintly amyloid over the entire length (sometimes more strongly in upper half), but intensely and unrestrictedly amyloid over the apex (most taxa in group VI, P. succosa and P. michelii); (ii) faintly amyloid over the entire length, except intensely amyloid in a distinct ring zone at the apex, restricted to the area of dehiscence of the operculum (a synapomorphy for group IV); (iii) evenly amyloid over the entire length, either: (iiia) weakly, perhaps slightly stronger at the apex, or diffusely amyloid [periascus and hymenial gel amyloid (Pfister 1973)], or rarely non-amyloid (Iodophanus, P. gerar- dii, group II, Pachyella, Boudiera, Amylascus, Hydnotryopsis, Plicaria, Tirmania, Ruhlandiella, P. natrophila, P. polaripapulata and Peziza sp. 4); (iiib) strongly amyloid (Iodowynnea, P. ellipsospora, P. luteoloflavida, P. retrocurvata, $P$. whitei and Sarcosphaera); (iv) Nonamyloid (Marcelleina and Cazia). The amyloid reaction is a fairly stable character, but rarely may be absent due to change of humidity (e.g., long periods of rain) or an overripe state of the hymenium, e.g., presumedly in Pfistera (van Brummelen 1998) and other Peziza species. The periascus (an extra-ascal mucilagenous coat, as defined by van Brummelen 1978) can also disappear after heating (Donadini 1985) or be removed in microscopic preparation by applying pressure on the cover slip and sliding it back and forth (Samuelsen 1978).

\section{DISCUSSION}

Overview.-The Pezizaceae appear to be paraphyletic as currently circumscribed (Eriksson 2000) because Marcelleina is nested within it. If Marcelleina is transferred to the Pezizaceae, then the family would be a strongly supported monophyletic group (FIGS. 2224). Our data fail to resolve the higher level relationships within the Pezizaceae (FIG. 23) or result in resolutions of relationships that are not well-supported by bootstrap analyses (FIG. 24). The weakness in our estimate of the phylogeny may be due to having too few informative characters, or to missing key taxa in our sampling (especially species of Peziza with apiculate spores). Addition of more characters from other molecules (such as the protein-coding nuclear genes Beta-tubulin or RPB2), and expansion of the set of taxa to include more aberrant species of Peziza, may improve resolution deep in the tree and "break up" long branches (Graybeal 1998). Nevertheless, seven groups of species are identified that may eventually be formally recognized. Confirming recent molecular studies, Peziza is not supported as monophyletic (Norman and Egger 1996, 1999). Peziza species are spread among all groups, except group III, and it is evident from this that Peziza will have to be subdivided into several genera, or a very wide concept

$\leftarrow$

FIG. 22. Phylogeny of the Pezizaceae inferred from nLSU-rDNA sequences. One of more than 15000 equally parsimonious trees (1832 steps), generated under gaps = missing coding. Terminal taxa represent individual specimens (TABLE II). Branches with asterisks collapse in the strict consensus of all most parsimonious trees. Numbers by branches are bootstrap frequencies (values greater than $50 \%$ ). Branch lengths are proportional to the number of steps (character changes) along the branch. Branch colors and dotted branches represent character state optimizations (using MacClade). Species of Peziza are in boldface. Taxa in grey are hypogeous, without forcible spore discharge. Bracketed groups I-VII are discussed in the text. Diamond indicates suggested position of $P$. vesiculosa from subsequent analysis (see note added after acceptance of the manuscript). 


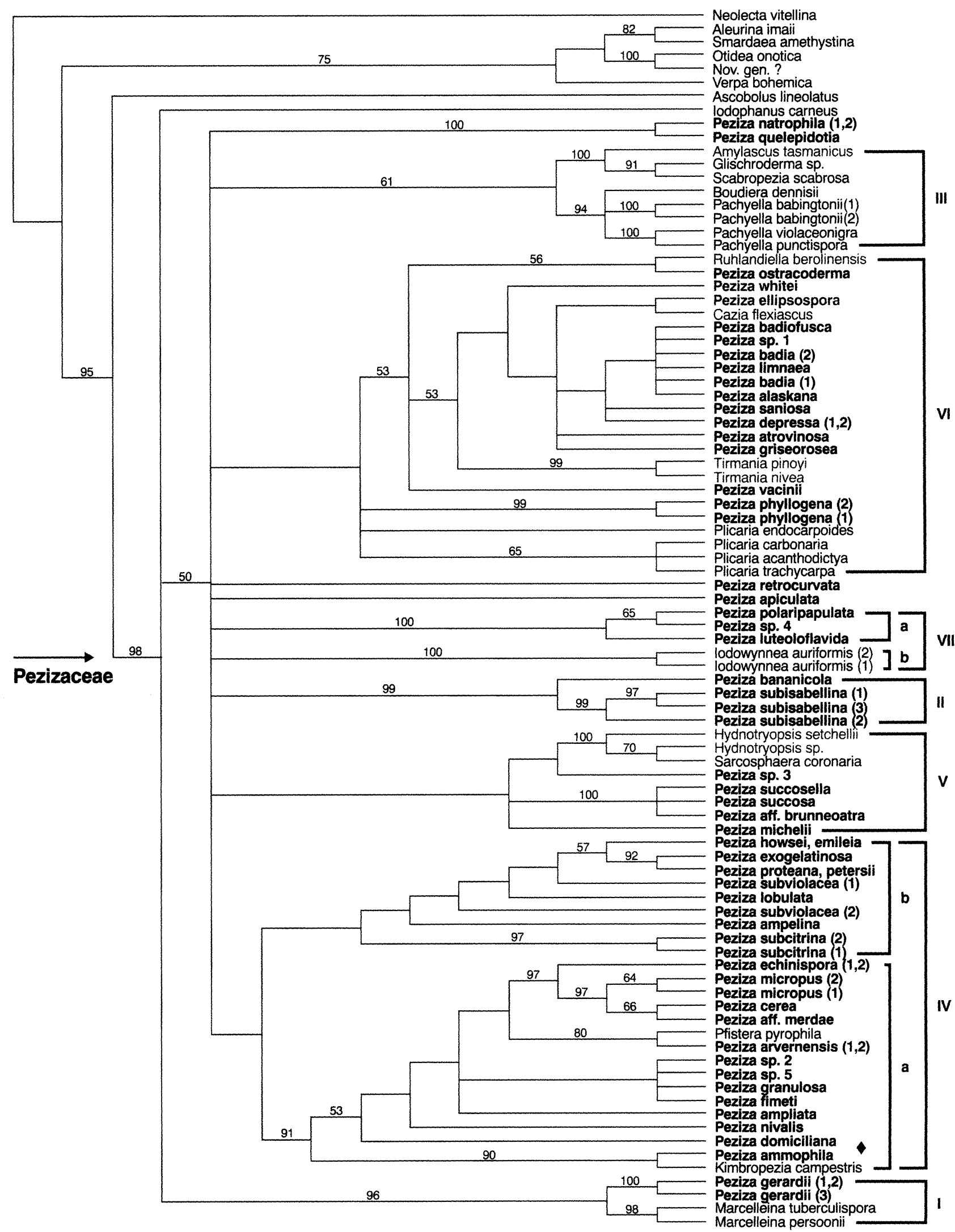

FIG. 23. Strict consensus of 15000 equally parsimonious trees generated under gaps = missing coding. Numbers by branches are bootstrap frequencies (values greater than 50\%). Species of Peziza are in boldface. Taxa in grey are hypogeous, without forcible spore discharge. Bracketed groups I-VII correspond to groups I-VII in FIG. 22. Diamond indicates suggested position of $P$. vesiculosa from subsequent analysis (see note added after acceptance of the manuscript). 
would have to be accepted, to better reflect phylogeny.

Ascomata forms and habit.-Four different forms of ascomata exist within the Pezizaceae. Epigeous apothecia of various shapes (TABLE I) with forcible spore discharge, are the most common and occur in groups I-VII. This form is likely to be symplesiomorphic, implying that the apothecia-forming members of the Pezizaceae have given rise to at least three different forms of hypogeous ascomata without forcible spore discharge (sensu Weber et al 1997): (i) ptychothecia: enclosed, hollow, subglobose to globose, often convolute ascomata, which may have one or a few open chambers, and a persistent, recognizable hymenium of asci and paraphyses typically lining the hollow chambers (FIGs. 17, 18) (in group VI); (ii) stereothecia: more or less solid, fleshy ascomata, with the asci either solitary, scattered relatively evenly throughout the medullary excipulum or grouped in dispersed pockets or meandering veins (FIGS. 8, 14) (in group III, V, VI); (iii) exothecia: solid, pulvinate to globose ascomata, in which the hymenium covers the outer surface (leaving no discernible margin) and permanently exposed, with the asci distinctly shorter than the paraphyses (FIG. 19) (in group VI).

At least three independent origins of hypogeous forms within the Pezizaceae were supported by the LSU rDNA gene trees (in group III, V and VI) (FIGS. $22,24)$. The most parsimonious interpretations of the molecular phylogenies suggest that forcible spore discharge has been lost once in group III; lost twice, or lost once and gained once in group V; and either lost twice and gained once, or lost once and gained twice in group VI (FIGS. 22, 24). However, separate constraint analyses forcing the hypogeous taxa within either group V or VI into monophyletic groups, could not be rejected using the Kishino-Hasegawa test (TABLE III). Forced monophyly of the hypogeous taxa within group VI, did not yield trees that were significantly worse $(P<0.05)$ than the unconstrained trees (TABLE III). Likewise, forced monophyly of the two species of Hydnotryopsis in group V could not be rejected $(P<0.05)$. Trees with constrained monophyly of the hypogeous taxa within groups V and VI, respectively, but analyzed together, were not significantly longer than the unconstrained MPTs $(P<$ $0.05)$. However, under this constraint the MLT was significantly worse than the unconstrained optimal MLT $(P<0.05)$ (TABLE III). The most conservative conclusion is thus, that forcible spore discharge has been lost only once within each of the groups $\mathrm{V}$ and VI.

Phylogeny within the Pezizaceae.-Group I. This is a highly supported clade (bootstrap 96\%) of the mor- phologically distinct Peziza gerardii and two species of Marcelleina, M. persoonii and M. tuberculispora. It is a likely sister group to the rest of the Pezizaceae (FIG. 24). Contrary to the current classification, which accepts Marcelleina in the Pyronemataceae (Eriksson 2000) or Otideaceae (Hawksworth et al 1995), our analyses place the non-amyloid Marcelleina in the Pezizaceae. The genus is restricted to species with small purplish apothecia, 2-10 $\mathrm{mm}$ in diam (FIG. 3), with light brown pigments in the walls of the hyphae in the outer excipulum and hyaline spores (Moravec 1987). The purplish (-brownish) pigments are found in the paraphyses and subhymenium. Smardaea and Aleurina, presumed to be closely related to Marcelleina (Zhuang and Korf 1986, Moravec 1987, Hansen et al 1998), are supported in the Pyronemataceae (grouping with Otidea and an undescribed genus (TL 6236)) (FIGS. 22, 23). Smardaea and Greletia Donadini (the latter not included in this study) are distinguished by purplish pigments in all parts of the apothecia, including the spore ornamentation, and by a clearly differentiated medullary excipulum (Svrček 1969, Donadini 1979c, Moravec 1987). Korf (1972) placed Marcelleina (as Pulparia P. Karst.) in the subfamily Ascodesmidoideae (Pyronemataceae). To him, the genus seemed to provide a link between Sphaerozone and Aleurina (as Jafneadelphus Rifai). Moravec (1987) revised and placed Marcelleina in a new subfamily, Aleurinoideae (Pyronemataceae), along with Aleurina, Eoaleurina Korf \& W.Y. Zhuang, Greletia, Smardaea and Sphaerosoma.

Although the Pezizaceae has generally been characterized by amyloid asci, these results indicate that the amyloid reaction might be lost (type iv) in some lineages, such as in the branch leading to Marcelleina (FIGS. 22, 24). Boudier (1907) placed species of Marcelleina (as Plicaria), including the type species $M$. persoonii, in the "Aleuriées" (= Pezizaceae), presumably based on the globose spores and the excipulum structure. He fully realized that the asci were nonamyloid (Boudier 1905-1910, plate 308). Eckblad (1968) also regarded Marcelleina to be very close to Plicaria, the non-amyloid asci being one of only a few differentiating characters. He placed it in the Pezizaceae, despite the non-amyloid asci, and concluded that it would be "... attaching too much importance to a single, widely distributed character to keep Marcelleina out of its otherwise close affinity to Plicaria and Peziza." Other contemporary taxonomists have considered Marcelleina as logically placed among the non-amyloid genera. However, morphological similarities between $P$. gerardii and Marcelleina (FIGS. 2, 3), Smardaea and Greletia were noted by Schumacher and Jenssen (1992).

Macroscopically, and in habitat requirements (en- 


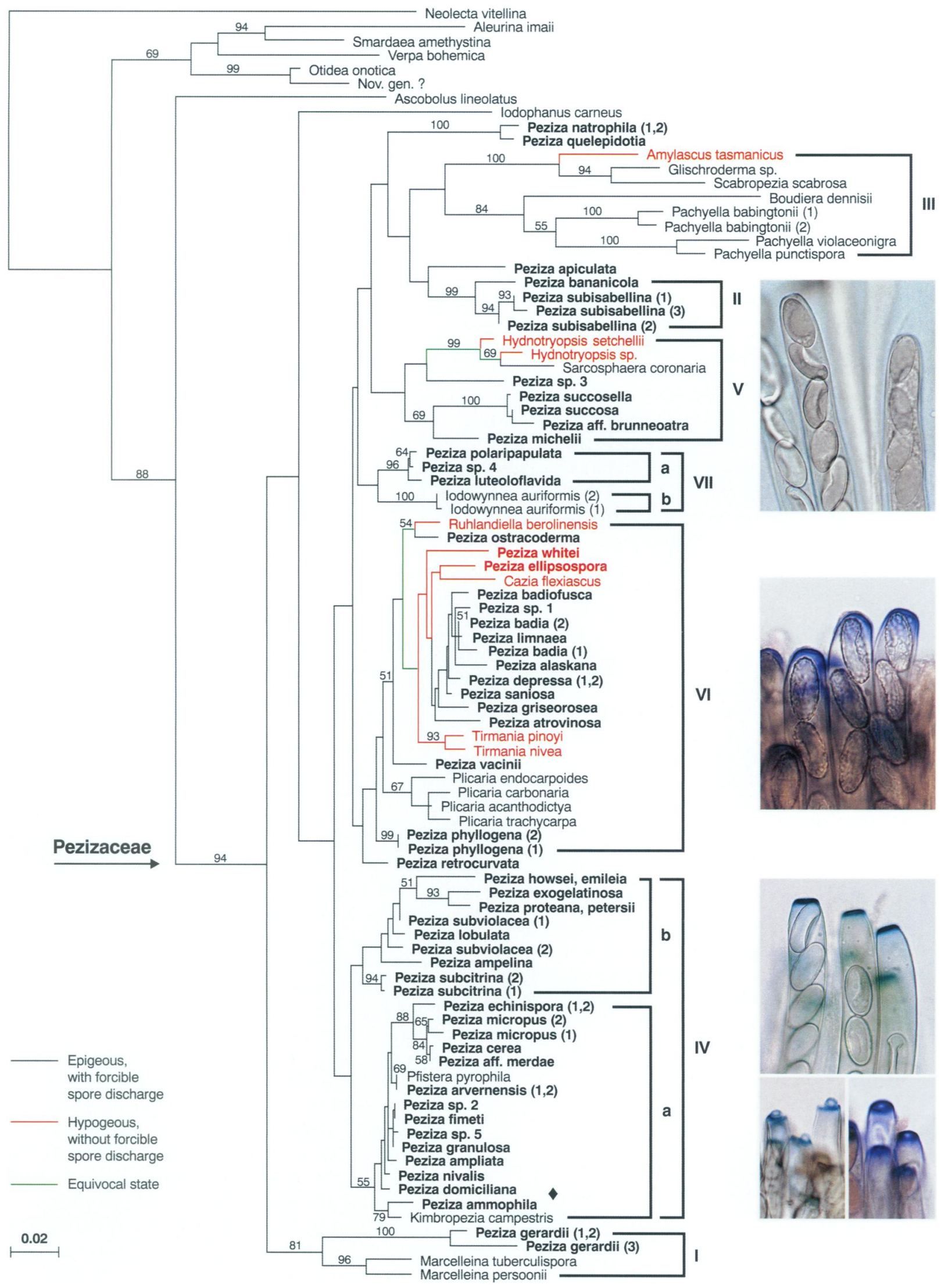


TABLE III. Evaluation of different constrained tree topologies in MP and ML analyses, compared to the MPTs and the optimal MLT, respectively, using the Kishino-Hasegawa test $(\mathrm{p}<0.05)$

\begin{tabular}{|c|c|c|c|c|c|c|}
\hline \multirow[b]{2}{*}{ Tree } & \multicolumn{2}{|l|}{ MP } & \multicolumn{4}{|c|}{ ML } \\
\hline & Tree length ${ }^{\mathrm{a}}$ & $\begin{array}{c}\text { Signifi- } \\
\text { cantly } \\
\text { worse? }\end{array}$ & Ln likelihood & $\begin{array}{c}\text { Difference } \\
\text { in } \mathrm{LnL}\end{array}$ & $\begin{array}{l}\text { Standard } \\
\text { deviation }\end{array}$ & $\begin{array}{c}\text { Signifi- } \\
\text { cantly } \\
\text { worse? }\end{array}$ \\
\hline Unconstrained optimal MLT & & & -11308.898 & & & \\
\hline Unconstrained MPT & 1832 & & & & & \\
\hline Hypogeous taxa within group VI monophyletic & $1839(+7)$ & no & -11348.976 & -40.078 & 27.051 & no \\
\hline Hypogeous taxa within group $\mathrm{V}$ monophyletic & $1835(+3)$ & no & -11326.140 & -17.243 & 25.651 & no \\
\hline $\begin{array}{l}\text { Hypogeous taxa within group VI and V both } \\
\text { monophyletic }\end{array}$ & $1842(+10)$ & no & -11352.500 & -43.602 & 16.248 & yes \\
\hline
\end{tabular}

a Difference in length between MPTs and constrained trees in parentheses.

riched, often calcareous soil), species of Marcelleina (FIG. 3) are very similar to P. gerardii (FIg. 2). Peziza gerardii shares anatomical characters with Marcellei$n a$, although the fusiform spores are very different. Within the Pezizaceae, $P$ gerardii has a unique spore shape and ornamentation (observed by SEM): large, slightly inequilateral, narrowly fusiform spores, with an ornamentation of low, longitudinal, cyanophobic ribs (Berthet 1970), and 1 to 3 large and several small guttules. Spores in Marcelleina are globose, smooth or ornamented, with one large guttule. The purplish (-brownish) pigments in $P$. gerardii are located in the paraphyses, subhymenium and excipulum. Peziza gerardii and species of Marcelleina have an excipulum composed entirely of globose to angular cells, which, toward the outer surface, become smaller (outer excipulum hardly discernible), and from which scattered short rows of cells project (appressed, hyphoid, septate hairs). The weakly amyloid, general staining of the asci (type iiia) in $P$. gerardii is also a distinct and rare feature within the genus Peziza.

Group II. This strongly supported (bootstrap 99\%) group includes two unusual species of Peziza, $P$. subisabellina (FIG. 4) and P. bananicola. Both species have asci that are diffusely amyloid (type iiia) (FIG. 24). Presumably based on this feature, $P$. subisabellina has recently been combined in Pachyella (FIG. 5) (Trimbach 1999), a placement in contradiction with our molecular results (FIGS. 22, 24) as well as the morphological characters. Diffusely amyloid asci are typical for the genus Pachyella, but $P$. subisabellina does not possess other pachyelloid characters (see Background Information). Spore shape and guttulation in Pachyella is uniform, broadly ellipsoid containing two large guttules, and differs from P. subisabellina which has almost fusiform spores with many small guttules. Our analyses support Pachyella in group III.

Peziza sect. Purpureodiscus G. Hirsch (Hirsch 1992) was proposed for P. subisabellina and P. kreiselii G. Hirsch, based on the diffusely amyloid asci, reddish pigments in the apothecia (FIG. 4), smooth spores without guttules and clavate paraphyses. A segregation of $P$. subisabellina from the "core group of Peziza species" is also supported by our analyses. Sequences from three different collections of $P$. subisabellina are included in this study, one occurring on wood (Winterhoff 8844) and two on soil (RK96.54, ALTA9029). Several differences in the LSU have accumulated between these individuals, with the two specimens on soil grouping together, although all three form a well-supported monophyletic group (bootstrap 99\%) (FIG. 22).

Peziza bananicola is one of the few strictly tropical Peziza species. It has two unique features: an extensive subiculum that covers and binds debris from ba-

$\leftarrow$

FIG. 24. The tree with the highest likelihood (lnL-11308), obtained from maximum-likelihood analyses. Branch lengths correspond to genetic distance (expected nucleotide substitutions per site). Numbers by branches are "fast" bootstrap frequencies (values greater than 50\%). Branch colors represent character state optimizations (using MacClade). Taxa in red are hypogeous, without forcible spore discharge. Species of Peziza are in boldface. Diamond indicates suggested position of $P$. vesiculosa from subsequent analysis (see note added after acceptance of the manuscript). Bracketed groups I-VII correspond to groups I-VII in FIG. 22. Types of ascus amyloid reactions supporting group II, IV and VI are shown. Microscopic photos: diffusely amyloid (type iii, P. subisabellina, RK96.54, at the top) ca $\times 400$; intensely and unrestrictedly amyloid over the apex (type i, P. badia, KH-97-84, in the middle) ca $\times 600$; intensely amyloid in a distinct ring zone at the apex (type ii, $P$. cerea, $\mathrm{KH}-97-01$, at the bottom) ca $\times 550$. Photos: K. Hansen. 
nana plants, and a peculiar spore ornamentation of sparse, irregularly spaced, very thin, acutely pointed spines (Pfister 1991). The spores are narrowly ellipsoid and eguttulate. Peziza subisabellina and P. bananicola share certain excipular features, being very thick and dense. However, the medullary excipulum is stratified in three layers in $P$. bananicola, but is composed of a single uniform layer in $P$. subisabellina. Other less known tropical species, e.g., P. luteorosella (Le Gal) Pfister and Galactinia tapesioides Le Gal (Le Gal 1960), are morphologically similar to $P$. bananicola (Pfister 1991) and may belong to group II. Peziza luteorosella has spore ornamentation much like $P$. bananicola, but has an unstratified excipulum like $P$. subisabellina. Hymenial colors in the three tropical species and $P$. subisabellina range from whitish, yellowish, rose, reddish to purplish brown.

Group III. Four genera and one form-genus are represented in this clade (bootstrap MPT $56 \%$, supported by all MPT, FIG. 23). Boudiera dennisii (FIG. 6) forms a monophyletic group with three species of Pachyella, P. violaceonigra, P. punctispora (FIG. 5) and P. babingtonii (bootstrap MPT 91\%, MLT 84\%). This is in contradiction with the ML analysis by Norman and Egger (1999) based on nSSU rDNA sequences. In their analysis Boudiera (B. acanthospora Dissing \& Schumacher) clusters with Iodophanus (FIG. 1), basally in the Pezizaceae ( $<50 \%$ bootstrap), which supports the placement of these genera in a tribe, Iodophaneae (Korf 1972, 1973b). However, Pachyella is not represented in the study by Norman and Egger (1999), since the included Pachyella is Peziza subisabellina (see Materials and Methods). A close relationship between Boudiera and Plicaria, as has been suggested (see Background Information), is also not supported by our analyses. Species of Boudiera lack gelatinous excipular tissues and hyphoid hairs embedded in a gel, typical in the genus Pachyella. Nevertheless, the lineage is united by asci evenly amyloid over the entire length (type iiia) and the overall anatomical structure of a medullary excipulum of textura intricata, an outer excipulum of textura angularis to globulosa and an indistinct subhymenium (TABle I). Species of Boudiera and Pachyella occur on water-soaked, regularly inundated substrates, although Pachyella species most commonly occur on wood, and Boudiera species on sand. The relationship between the two genera is unresolved in the strict consensus tree, but monophyly of Pachyella is weakly supported in the MLT ( $55 \%$ bootstrap). The two subclades of Pachyella species are both highly supported ( $100 \%$ bootstrap). Some of the longest branches in the MPT (FIG. 22) occur in group III. The branch leading to Boudiera is 63 steps. The branches uniting the lineages of $P$. violaceonigra and $P$. punctispora, and the lineages of P. babingtonii are each 42 and 26 steps. The branch uniting the lineages of Boudiera and Pachyella is 39 steps. Long internode lengths could most probably be obviated in this clade by including more species of Boudiera and Pachyella.

Scabropezia and the mitosporic Glischroderma Fuckel form a highly supported clade with the truffle Amylascus tasmanicus (bootstrap 100\%). Another truffle, Pachyphloeus melanoxanthus (type of Pachyphloeus), is suggested as closely related to Scabropezia, based on nSSU rDNA sequences (Norman and Egger 1999) and morphology (Dissing and Pfister 1981). Both truffles produce ascomata with a tough-fleshy medullary excipulum and asci randomly distributed throughout the tissue (= stereothecia) (Fig. 8). The asci are weakly amyloid over the entire length (type iiia), but some other species of Pachyphloeus are described with non-amyloid asci (Dissing and Korf 1980, Dissing 2000). Dissing and Pfister (1981) noted the similarities in the structure of the outer excipular layers in Pachyphloeus and Scabropezia, which is highly pustulate or verrucose (Fig. 7), of thick-walled, large, globose cells, a feature also shared with Amylascus (Trappe 1971, 1975b, Beaton and Weste 1982). Scabropezia scabrosa, A. tasmanicus and P. melanoxanthus have globose spores, with an ornamentation of prominent conical or truncate warts, which in $P$. melanoxanthus and A. tasmanicus are embedded in mucilage. The spores in Scabropezia and P. melanoxanthus are brownish at maturity. Scabropezia often occurs on calcareous soil, or rarely on decaying wood, and attempts to germinate spores of Scabropezia failed (Dissing and Pfister 1981). Based on these observations, and the fact that most hypogeous fungi are thought to be ectomycorrhizal (Trappe and Maser 1977), we believe this lineage could be mycorrhizal.

Group IV. This group is weakly supported by bootstrap analyses $(<50 \%)$, but is present in all MPTs (FIG. 23) and in the MLT (FIG. 24). The presence of a distinct amyloid ring zone at the apex of the asci (type ii, FIG. 24) is a synapomorphy for group IV. Such a reaction is present in all species, except in Kimbropezia, in which asci are strongly amyloid apically (Korf and Zhuang 1991), and in P. emileia, P. howsei and $P$. ampelina, which show a less restricted amyloid reaction, although $P$. howsei (KH-97-98) showed a distinctly amyloid ring zone in fresh material. Asci with a strongly amyloid ring were noted previously by Svrček (1970) in several of the species in clade IVa. Group IV is also united by the type of anamorph produced. All species with known anamorphs produce an Oedocephalum state. An exception is Peziza aff. merdae which produces a Chromelosporium state (Norman and Egger 1999). Oedocephalum anamorphs are reported for species in both clade 
IVa (for P. ammophila, P. ampliata, $P$. cerea, $P$. echinispora, $P$. micropus, $P$ repanda, $P$. sylvestris, $P$. varia and $P$. vesiculosa) and in IVb [for $P$. subviolacea (as $P$. praetervisa), $P$. petersii and $P$. lobulata (as Galactinia violacea (Pers.) Le Gal) ] (e.g., Berthet 1964a, b, Paden 1972, 1973, Webster et al 1964). Additionally, spores with a unilateral gelatinous coating have only been found in group IV. The gelatinous spore coating was observed in P. ampliata, $P$. granulosa, $P$. subcitrina and $P$. vesiculosa. This character has rarely been reported, probably because it is difficult to observe in dried material.

Group IV includes one strongly supported clade, IVa, with bootstrap MPT 91\%, MLT 55\% (equivalent to Boudier's genus Aleuria pro parte 1907). This clade contains common Peziza taxa, characterized by mostly large, yellowish brown disc- to cup-shaped apothecia (FIG. 9), finely warted or smooth, eguttulate spores $(P$. domiciliana has two small guttules in the spores), and simple, hyaline or pale yellowish paraphyses. They occur on rich soil mixed with litter or woody debris or mortar, on strongly decayed trunks, manured substrate or dung. A subset of these taxa was also highly supported as monophyletic in ML analysis by Norman and Egger (1999). Since the type species of Peziza, P. vesiculosa, is included, this clade will have to serve as a core group for a future circumscription of the genus.

Morphological, ecological, and molecular divergence (nLSU rDNA) based on the branch lengths (FIGs. 22, 24) and nucleotide diversity are low within group IVa, which may suggest a recent radiation. Additionally, species limits are controversial and the number of species recognized varies. The group is taxonomically problematic due to lack of diagnostic morphological characters. Peziza species with ellipsoid, smooth, small (ca $15 \mu \mathrm{m})$ and eguttulate spores were referred to as the "Peziza repanda-varia-micropus-cerea complex" by Rifai (1968). He stated that this complex needs a prolonged field and laboratory study to establish species limits. The most detailed study of this complex is by Svrček (1970), who also included species with finely warted spores. A detailed study of group IVa using morphology and more rapidly evolving sequences is in progress.

Peziza ammophila differs in its habitat and development. It fruits partly buried in sand (FIG. 10), among Ammophila (Poaceae). The (pseudo-)stipitate ascomata are deeply cup-shaped and the margins split into irregular rays, becoming flattened on the sand surface. Based on this characteristic development, P. ammophila has been placed in Sarcosphaera (FIG. 13) (e.g., Kotlaba and Pouzar 1963, Seaver 1928). Pouzar (1972) considered P. ammophila and another species, $P$. austrogaster (Rodway) Rifai, to be a "unique" entity within Peziza. He proposed a new subgenus of Peziza, Asterosphaera Pouz., with P. ammophila as the type species. Most authors have considered the similarities in macromorphological development between Sarcosphaera and P. ammophila to be a result of convergent or parallel evolution. These hypotheses is congruent with the molecular results. Furthermore, P. ammophila shares all other morphological characters of clade IVa. Peziza echinispora differs from other members of this clade in its spore ornamentation of isolated, regular spines and its occurrence on burnt ground. Other characters such as eguttulate spores, an Oedocephalum anamorph, and the distinctly amyloid ascus ring zone, justify its placement in this group. Apart from the guttulate spores, $P$. domiciliana is also aberrant in this clade by having a pinkish (violet) tinge in the hymenium otherwise characteristic of clade IVb.

The monotypic genera Kimbropezia and Pfistera, described on the basis of peculiar ascus apices (Korf and Zhuang 1991) are nested within clade IVa. Kimbropezia campestris was assigned to the Pezizaceae, while Pfistera was excluded due to the supposedly non-amyloid asci. Asci in Pfistera pyrophila were described as having a very thin, arched apical dome at maturity, which may split vertically, horizontally or irregularly. Van Brummelen (1998) studied the ascus apical structures in these species, and in species he supposed might be related [ $P$. michelii, $P$. emileia and Geopyxis majalis (Fr.) Sacc.] using TEM. Our results support van Brummelen's conclusion, that Pfistera campestris belongs in Peziza. It was found to display two different types of ascus dehiscence, the second type perhaps developing from the first type, resulting from less than optimum conditions during development. The apical structure of the "typical" ascus was of the Peziza type. In addition, Pfistera pyrophila shows several characters that are typical for clade IVa and microscopic examination (by DHP and $\mathrm{KH}$ ) revealed a few small patches of faintly amyloid material in the hymenium, around some ascal tips (pretreated with $2 \% \mathrm{KOH}$ ). Van Brummelen observed "remains of a moderately reactive periascus, too thin to be observed by light microscopy." Contrary to the phylogenetic analysis by Norman and Egger (1999) and to our results, van Brummelen considered Kimbropezia to be distinct from Peziza. He found that asci of Kimbropezia, in addition to having the unique "opercular lens," was more strongly amyloid than those of Pezi$z a$, and the annular indentation or weakened zone characteristic of Peziza was completely absent. Dehiscence was found to be by a circumscissile, rather irregularly delimited rupture in the thin part of the ascus wall, around the opercular lens. We suggest that this apical structure and the mechanism of dehis- 
cence are derived within clade IVa from a typical $P e$ ziza-type and that the "opercular lens" is an autapomorphy. The excipulum structure in Kimbropezia is, as also pointed out by Korf and Zhuang (1991), typical for species in clade IVa; the spores are ellipsoid, smooth and eguttulate (TABLE I). Therefore, Kimbropezia should be included in Peziza. The operculate dehiscence has been lost completely several times within Peziza (e.g., see Group VI) and the Pezizales (e.g., Trappe 1979, O'Donnell et al 1997, Percudani et al 1999). It should be noted that in ML analysis by Norman and Egger (1999) the truffle Terfezia terfezioides (Matt.) Trappe is supported within, or as a sister lineage to, group IV based on $\mathrm{nSSU}$ rDNA.

An assemblage of nine Peziza species, clade IVb, is a sister group to clade IVa. Clade IVb, like IVa has mostly smooth or warted spores, but mostly have two, small guttules. Common to this group are apothecia with violaceous to vinaceous pigments in the hymenium (FIG. 11), either dark and intense or at least with a pink, bluish or lilaceus tinge. Peziza subcitrina deviates in its golden yellow ascomata (FIG. 12) and eguttulate spores. Peziza lobulata has eguttulate spores, while $P$. proteana and $P$. petersii have spores with low, short branched ridges and warts. Four of the species are pyrophilous, $P$. petersii, $P$. proteana, $P$. subviolace and $P$. lobulata. Peziza exogelatinosa occurs on naked calcareous soil, with a high $\mathrm{pH}$ and a low content of organic matter similar to the conditions on burnt ground. Peziza ampelina, P. subcitrina, $P$. emileia and $P$. howsei are found on naked, clayey soil in rich deciduous forests.

The two clades in group IV recall to some degree Boudiers (1907) classification, based mainly on presence or absence of guttules. Peziza species in clade IVa were placed in the genus Aleuria ( $P$. domiciliana and $P$. ammophila were not treated by Boudier), whereas species in clade IVb were treated in both Aleuria and Galactinia. Although these phylogenetic results suggest that guttulation is a homoplasious character that has been lost and gained several times, a second interpretation is possible. The oil guttules in clade IV are smaller and less prominent than those in, e.g., Peziza species in group VI, and these two types may not be homologous. Guttules may, however, always be present to a greater or lesser degree, but the character may not be expressed in some species. If such is the case, lack of guttules is not phylogenetically informative. The "outlines" of two guttules have been observed (by $\mathrm{KH}$ in fresh material) in the spores of several specimens of group IVa. These "outlines" appear as aggregations of many smaller oil drops, after pretreatment in $10 \% \mathrm{KOH}$, staining with Sudan black in alcohol (a lipid stain) and clearing with $50 \%$ alcohol.

Group $V$. In these analyses, Sarcosphaera and two species of the hypogeous Hydnotryopsis, H. setchellii and $H$. sp. form a highly supported clade within group V (bootstrap 100\%) (FIGS. 22-24). The ascomata of Hydnotryopsis have hymenia located in labyrinthiform chambers or meandering veins, but these are folded and compressed, making them solid (= stereothecia) (FIG. 14) (Trappe 1979). Hypogeous fruiting of Sarcosphaera may occur (Trappe 1975a, 1979). In such cases the apothecia occasionally become folded and form chambers, thus resembling ptychothecia, but the asci retain functional opercula. Sarcosphaera coronaria fruits in spring to early summer and its development is likely associated with selection for reduction in water loss, as it is thought to be in truffles (e.g., Thiers 1984). The excipulum is thick and tough, probably also correlated with microclimatic aridity and initial development underground. It is composed of a distinct outer layer $(\mathrm{ca} 750 \mu \mathrm{m})$ of textura epidermoidea to textura prismatica on the outermost region, a medullary layer (ca $450 \mu \mathrm{m}$ ) of large globose cells and a subhymenium of smaller globose cells. A close relationship between Sarcosphaera and Hydnotryopsis has not previously been suggested. Trappe (1979) suggested that, "in its evolution to a solid gleba, Hydnotryopsis is related to Peziza a step farther away than Mycoclelandia." Sarcosphaera differs anatomically from Peziza in the outer excipular layer. Hydnotryopsis and Sarcosphaera both have asci evenly amyloid over the entire length (type iii), and ellipsoid, amorphous ornamented spores (in SEM spores of Sarcosphaera have an ornamentation of low, rounded warts, covered by a thin amorphous layer). Sarcosphaera is only found associated with mycorrhiza-forming trees, and is often locally abundant where it occurs, year after year in the same spot, suggesting that it is ectomycorrhizal. Basal to these taxa is an as yet unidentified species of Peziza sp. 3, collected on experimental plots treated with urea (supported by all MPT's and the MLT, but bootstrap $<50 \%$ ). It shares features with species of Peziza in group IV (a whitish, cup-shaped apothecium, smooth, biguttulate spores, and hyaline or pale yellowish paraphyses, slightly enlarged and curved towards the apices), but has asci strongly amyloid over the apex.

The Hydnotryopsis/Sarcosphaera clade appears as a sister group to common epigeous species of Peziza sharing features with those in group VI. However, $P e$ ziza succosa, $P$. succosella and $P$. michelii possess lactiferous hyphae in the excipulum, which yield a yellow juice when cut or bruised. Peziza species with apothecia that yield a colored juice are also present in 
group VI (for example $P$. saniosa (FIG. 15) and $P$. badiofusca), but in these hyphae yield a bluish or watery juice. This character however, needs further study, since lactiferous hyphae are likely to be present in many species of Peziza. Thus, Le Gal $(1937,1953 a)$ described and illustrated lactiferous hyphae also in species without or seemingly without staining flesh or juice. Peziza succosa, $P$. succosella and $P$. michelii have spores with irregular, elongated warts and two large guttules, asci strongly amyloid over the apex (type i), and brownish colors in the hymenium (yellowish brown, olivaceous yellow to greyish brown, or first violet, then brownish). They occur on rich disturbed soil in deciduous forests, always in association with ectomycorrhizal fungi. Peziza aff. brunneoatra deviates by having dark brown apothecia, lacking a yellow juice and in having finely warted spores packed with numerous small guttules (sensu Dennis (1978) in Norman and Egger (1999)).

Group VI. Although group VI has low bootstrap support $(<50 \%)$, it is present in all equally parsimonious trees (FIG. 23) and in the MLT (FIG. 24). It includes one weakly supported clade (bootstrap MPT $53 \%$, MLT 51\%) of 11 epigeous species of Peziza (equivalent to Boudier's genus Galactinia pro parte 1907) and several truffles and truffle-like taxa. The epigeous Peziza species are united morphologically by mostly dark brownish, disc- to cupshaped apothecia, often with an olivaceous or purple tinge; highly warted, ridged to reticulate spores, with two, rarely one, large guttules; dark pigmented paraphyses; and asci intensely and unrestrictedly amyloid over the apex (type i). The hypogeous taxa have asci that are evenly amyloid over the entire length, either weakly or strongly (type iii), or are non-amyloid (type iv).

The relationship of several of the epigeous ellipsoid-spored species has been studied, and discussed in relation to the globose-spored Plicaria (Pfister 1979b, Egger 1987, Moravec and Spooner 1988, Norman and Egger 1996, 1999) (see Background Information for previous hypotheses). Our analyses confirm a close relationship of Plicaria (FIG. 16) to the more inclusive Peziza clade within group VI (FIG. 15). Plicaria is supported as monophyletic in the MLT (bootstrap 67\%) (FIG. 24), but the placement of the smooth-spored $P$. endocarpoides (the only smoothspored species in group VI) is unresolved in the MPTs (FIGS. 22, 23). The three Plicaria species with ornamented spores are supported as monophyletic with a $65 \%$ bootstrap value. Globose, ellipsoid to fusiform-spored taxa group together in several lineages within the Pezizaceae (in group I, III, VI) (TABLE I), indicating that spore shape is not phylogenetically informative at these higher taxonomic levels. As shown by Norman and Egger $(1996,1999)$ to maintain Pli- caria as a monophyletic group will leave Peziza (or the Peziza species in group VI) as a paraphyletic group. Some important characters of Plicaria are shared with some of the Peziza species, e.g., pale brownish spores at maturity and paraphyses encrusted with amorphous matter. Such characters seem to be synapomorphic to the Peziza species in group VI. Pale brownish spores are found in $P$ atrovinosa, $P$. vacinii and $P$. alaskana. Paraphyses encrusted with amorphous matter are present in $P$. alaskana, $P$. badiofusca, Peziza sp. 1, P. vacinii, $P$. depressa and $P$. phyllogena. Other Peziza species reported with pale brownish spores, e.g., $P$. retiderma and $P$. rifaii (Moravec and Spooner 1988), and paraphyses encrusted with amorphous matter, e.g., P. badiofuscoides Donadini (Donadini 1979b), are likely members of group VI, but have not been sequenced by us. In contrast to the rest of the epigeous taxa in group VI, the asci in Plicaria are weakly amyloid over their entire length (type iiia).

The 11 epigeous Peziza species in the more inclusive clade of group VI constitute a homogeneous group, both in macro- and microscopical features, and levels of divergence in the nLSU rDNA sequences are low based on the branch lengths (FIGS. 22, 24). The clade of $P$. badiofusca, Peziza sp. 1, P. badia, $P$. limnaea and $P$. alaskana (FIGs. 22-24) represents a complex of species centering around $P$. badia (see Le Gal 1937, Donadini 1979b, Pfister 1979b), that possesses spores with ornamentations of warts elongated into short ridges, which may anastomose to form an incomplete to almost complete, irregular reticulum. Less known unsampled species that may belong to this clade are $P$. phlebospora (Le Gal) Donadini, $P$. badiofuscoides and $P$. badioides Donadini. A closer study of these species, mainly distinguished by small differences in spore size and ornamentation and in habitat, is needed. Peziza depressa differs from members of this group by having spores ornamented with distinct, regular, high warts, and a warm reddish brown hymenium. Peziza saniosa, P. badiofuscoides and $P$. badiofusca are distinct by possessing apothecia that yield a bluish, blue opalescent or watery juice when cut or bruised (FIG. 15).

Peziza phyllogena (syn. P. kallioi Harmaja, P. badioconfusa Korf ss. auct.) is included in group VI, but outside the core group of Peziza species (next to Plicaria) in the MLT (FIG. 24); its relationship to the rest of the clade is not resolved in the strict consensus tree (FIG. 23). It shares many features with the group VI Peziza species, and it has been confused with $P$. badia (Korf 1954, Elliott and Kaufert 1974). It is recognized by the bluish violet, pubescent to villose base of the apothecium (seen easily on fresh material); spores ornamented with delicate, irregular warts, 
which become fused towards the poles, often forming apical caps; and its fruiting habit, on decaying wood or woody debris in wet habitats (Wells and Kempton 1967, Elliott and Kaufert 1974, Ginns 1980, Harmaja 1986). Its spores do not possess two large guttules as is typical for the group VI Peziza species, but rather have many small guttules that aggregate towards the poles.

The truffles and truffle-like taxa nested within group VI show diverse ascomatal forms. Two hypogeous species of Peziza, P. whitei (FIG. 18) and P. ellipsospora (FIG. 17), produce ptychothecia (TABLE I) (Gilkey 1916, Trappe 1975a, 1979, Beaton and Weste 1982). Both species have hyaline, broadly ellipsoid spores, which are minutely papillose in $P$. ellipsospora and reticulate in $P$. whitei. Gilkey (1916) described $P$. ellipsospora in Hydnotrya Berk. \& Broome, based on the macro-morphology, but erected a new genus, Hydnoplicata Gilkey for P. whitei (Gilkey 1954a). Peziza whitei has been placed in Hydnocystis Tul. and Hydnotrya (see Trappe 1975a). Burdsall and Korf (Burdsall 1968) and Trappe (1975a, 1979) transferred the two species to Peziza, based on the amyloid reaction of the asci, spore ornamentation, ascocarp structure, and supposedly operculate asci. Later Trappe (pers comm) found that these species lack an operculum and the spores are not forcibly discharged. Our molecular results support the placement of the two species among the core group of epigeous Peziza species in group VI (FIGS. 22-24). Peziza ellipsospora is a sister species to Cazia. Other phylogenetic analyses (Norman and Egger 1999, Percudani et al 1999) have further shown Cazia to be closely related to the truffle Terfezia arenaria (Moris) Trappe. Cazia and Terfezia produce stereothecia and both have non-amyloid asci (type iv) (TABLE I). As in the branches leading to Marcelleina (in group I) and Terfezia terfezioides (possibly in group IV based on Norman and Egger 1999), the amyloid reaction might be lost along a branch leading to Cazia flexiascus and Terfezia arenaria. This suggests that the amyloid reaction has been lost at least three times within the Pezizaceae. Cazia flexiascus has ellipsoid, hyaline, incompletely warty-reticulate spores, with one guttule (Trappe 1989), much like the spores of P. whitei and P. ellipsospora. Two species of Tirmania, $T$. nivea and $T$. pinoyi, also producing stereothecia (Trappe 1971, Moreno et al 2000), are nested within group VI. They group strongly together (bootstrap MPT 99\%, MLT 93\%) as a sister group to most of the epigeous and the hypogeous Peziza species and Cazia (FIGs. 23-24). The similarity in excipulum structure between Cazia, Terfezia and Tirmania adds support to the close relationship between these taxa (TABLE I).
Ruhlandiella berolinensis produces exothecia (FIG. 19) (Dissing and Korf 1980, Warcup and Talbot 1989 as Muciturbo, Galán and Moreno 1998). The excipulum is composed entirely of globose to angular cells. Asci are evanescent at maturity. The paraphyses in both $R$. berolinensis and $P$. whitei exceed the asci and are embedded in a gelatinous sheath. Spores in $R$. berolinensis are probably dispersed when the hymenium and upper part of the ascoma break down to form a mucilaginous mass. Ruhlandiella berolinensis groups with $P$. ostracoderma in all trees (FIGS. 2224), but with low bootstrap support.

Few anamorphs have been reported for the group VI taxa, but where reported they are referable to Chromelosporium (Peziza ostracoderma, Plicaria endocarpoides, $P$. trachycarpa), Chromelosporium-like states (Ruhlandiella), or are unnamed states, producing hyaline to colored, 0-3 septate resting spores [P. saniosa, P. phyllogena as Galactinia badioconfusa (Korf) Svrček] (Berthet 1964a, b, Paden 1972, Hennebert 1973, Hennebert and Korf 1975, Warcup and Talbot 1989). Most of the epigeous Peziza species occur on bare, often disturbed soil, under ectomycorrhizaforming trees. Plicaria species and Peziza vacinii are pyrophilous, while $P$. ostracoderma also occurs on other types of sterilized soil and $P$. griseorosea on very degraded wood or soil mixed with wood.

Group VII. Two highly supported clades, VIIa and VIIb (bootstrap 96\% to 100\%) are united in group VII, but with only weak support in the MLT and the MPT (bootstrap <50\%) (FIG. 22, 24). Clade VIIa includes three species of Peziza, $P$. polaripapulata, $P$. sp. 4 and $P$. luteoloflavida. The apothecial colors of these species are in the range of pale yellow, ochre-yellow, warm yellow, brownish yellow to golden brown, dark brown with an olivaceous tinge, or olive yellow to olive (FIG. 20) (Kristiansen and Schumacher 1993, Hansen et al 1998). They are united by asci being evenly amyloid over the entire length (type iii). The spores contain two small guttules or are eguttulate. Peziza sp. 4 has smooth spores (in SEM), whereas $P$. luteoloflavida has spores with a fine, irregular, undulating reticulum, and $P$. polaripapulata has spores with isolated, rounded to elongated warts, becoming more or less fused at the poles to a cap-like thickening. Based on the spore ornamentation P. polaripapulata has been placed with the "pseudoapiculate Peziza species" in subgenus Phaeopezia (Sacc.) J. Moravec (Häffner 1995), along with $P$. phyllogena and the apiculate-spored P. apiculata. A close relationship of these taxa is not supported in our analyses, which places $P$. phyllogena in group VI and $P$. apiculata either as a sister lineage to group II or III. However, to test the monophyly of taxa with pseudoapiculate and apiculate spores, more sampling is necessary. Peziza 
polaripapulata (FIG. 20) occurs on very degraded hardwood, sawdust or soil in calcareous forests and P. luteoloflavida on sand on river banks. Peziza sp. 4 was collected among mossess, on a forest road surfaced with cinders.

Clade VIIb consists of two collections of the strictly subtropical or tropical genus, Iodowynnea. Our results support the segregation of Iodowynnea from the main groups of Peziza, but a close relationship to the Peziza species in clade VIIa is possible. The asci in Iodowynnea auriformis are evenly and strongly amyloid over the entire length (type iiib), and the apothecial colors have red tones. It fruits on soil or vegetable debris in forests with ectomyccorhizal trees (Medel et al 1996).

Taxa not supported in group I-VII. Peziza natrophila and $P$. quelepidotia form a highly supported lineage (bootstrap 100\%, Figs. 22-24), the placement of which is unresolved. But, in our analyses this group never falls within the main groups of Peziza. This observation is supported by the ascus amyloid reaction in P. natrophila, which is weak over the entire length (type iiia). Peziza quelepidotia was placed in its own genus Lepidotia, recognized by ellipsoid, eguttulate spores and distinctly stipitate or obconical apothecia with triangular, submembranaceous scales (Boudier 1885). On morphological grounds Korf and O'Donnell (Korf 1973c) did not consider Lepidotia generically different from Peziza s.l. In contrast Norman and Egger (1999), on molecular phylogenetic grounds, stated that $P$. quelepidotia is not a member of Peziza, and should be maintained in Lepidotia. Although, in their analysis P. quelepidotia forms a clade with $P$. subisabellina (in Norman and Egger misnamed as Pachyella clypeata). In our MLT (FIG. 24) the lineage of $P$. natrophila and $P$. quelepidotia is the sister group to the clade of group II (including $P$. subisabellina) and group III. Peziza natrophila is mostly known from experimental plots treated with sodium- and potassium carbonate (Petersen 1970, Khan 1976), but one of our specimens, P. natrophila (2) (JHP 93.021), occurred on soil in an old peat bog. This is similar to the substrate reported for P. quelepidotia, Sphagnum-pots and peat-moss agar ("Jiffy-7 Pellet infusion agar") (Korf 1973c, O'Donnell and Beneke 1973). The apothecia of $P$. natrophila are olivaceous brown, subsessile or stalked $(2-10 \mathrm{~mm}$ high), with an outer surface covered by short branching hyphae, much as described for P. quelepidotia by Korf (1973c). Peziza natrophila has distinctly ornamented spores, while $P$. quelepidotia is illustrated with less dense markings. Until further comparative studies have been carried out we cannot exclude the possibility that these species are con-specific.
Taxonomic conclusions.-The 14 genera sampled by us, and currently accepted in the Pezizaceae (Eriksson 2000), are confirmed to be members of the family. The analyses, however, suggest that the Pezizaceae should be emended to include the non-amyloid genus Marcelleina. The Ascobolaceae is confirmed to be the sister group to the Pezizaceae, which supports the general view that the amyloid reaction of the ascus is phylogenetically informative in the Pezizales. Peziza and most other genera of the Pezizaceae, as they are currently delimited, cannot be maintained in a monophyletic classification system. Peziza is composed of at least 6 major lineages, most of which include other genera of the Pezizaceae, and 4 species of Peziza occur in separate lineages of yet uncertain placement. Peziza should be disassembled into groups that more closely reflect the phylogeny, and several genera now recognized in the family require emendation or change in status. Group IV includes the type species of Peziza, P. vesiculosa, and should serve as a core group for a future circumscription of Peziza. The genera Kimbropezia and Pfistera should be included in Peziza. A close relationship between Sarcosphaera and the truffle Hydnotryopsis is suggested for the first time. Likewise, a close relationship between Scabropezia and the truffle Amylascus is strongly indicated.

Overall, these LSU analyses imply that there has been extensive homoplasy in some of the morphological characters that previously have been used to delimit taxa. Hypogeous ascomata with concomitant loss of active spore discharge have evolved independently several times, suggesting that their derivation from apothecial Pezizaceae may involve relatively simple genetic changes. For example, stereothecia have been derived within group III, V and VI. In addition, ptychothecia and exothecia have evolved within group VI. Derivation of ptychothecia and stereothecia from apothecia involves the evolution of enclosed hymenia or asci, while the derivation of exothecia involves the evolution of extremely convex hymenia. Spore shape has been emphasized in the delimitation of genera, but our results indicate that species with divergent spore form may be closely related. Globosespored species occur in group I, III and VI, along with ellipsoid- or fusiform-spored species. The amyloid reaction of the ascus appears to be a variable character that has been lost in some lineages. On the other hand, different types of ascus amyloid reactions correspond to different lineages and seem to provide clues to relationships within the Pezizaceae. Other characters, such as apothecial colors, spore surface relief, guttulation, excipulum structure and anamorph morphologies, seem to be phylogenetically informative, although considerable variation within 
and between groups occur. For example, apothecial colors are purplish in group I, in the range of yellowish, rose, reddish to purplish (brown) in group III, paler yellowish-brown in group IVa, violaceous to vinaceous in group IVb, and dark brownish in group VI. Smooth or finely verrucose spores, without or with two small guttules, are mostly present in group IV species, while highly ornamented spores with two large guttules occur mostly in group VI species. Excipulum structure, although not clear-cut, seem to be fairly uniform within most groups. Oedocephalum anamorphs are produced by taxa in group III and IV, and by species of Iodophanus, while Chromelosporium anamorphs are produced mainly by group VI taxa.

It is still premature to propose a phylogenetic classification of the Pezizaceae. For example, the monophyly of some of the genera, e.g., Boudiera and Scabropezia, has not been tested and six genera (TABLE I) are not represented in this study. Most importantly, an additional dataset is needed to provide a more robust estimate of the phylogeny. Further studies of morphological characters, especially of pigment composition and excipulum structure, and of anamorph type and trophic status in the context of a robust molecular phylogeny, that will facilitate refining hypotheses of homology, may be useful in understanding relationships within the Pezizaceae.

Note on $P$. vesiculosa added after acceptance of the manuscript.

In a detailed and large scale study now underway of the group IVa Peziza species using ITS rDNA sequences it was discovered that the published voucher specimen for P. vesiculosa (ALTA 9066, GenBank LSU: AF133170, SSU: AF133155, ITS: AF133182) (Norman and Egger 1999) was misidentified. The specimen (ALTA 9066) has been examined morphologically by $\mathrm{K}$. Hansen and has been determined to be Peziza fimeti. A comparison of the ITS1 sequence of ALTA 9066 with the larger ITS data set confirms this finding. In this paper ALTA 9066 has been renamed $P$. fimeti in FIGS. 22, 23 AND 24, and in TABLE II. Unfortunately, this misidentification has resulted in $P$. vesiculosa, the type species of Peziza, being omitted from the study. However, we have now sequenced the LSU rDNA (D1 and D2) from a collection of $P$. vesiculosa (TL-6398, C) (GenBank AF378367), and analyses of our LSU dataset including this sequence suggest that group IVa does in fact include $P$. vesiculosa (bootstrap 86\%). The presence of a distinct amyloid ascus ring zone in $P$. vesiculos a also supports this placement. The placement of $P$. vesiculosa within group IVa is unresolved in the strict consensus tree of the MPT's based on LSU, but ITS sequences suggest a possible relationship with $P$. ammophila.

\section{ACKNOWLEDGEMENTS}

We are grateful to David S. Hibbett and Henning Knudsen for valuable discussions and encouragement throughout, and for making helpful comments on the manuscript, and all members of the Donoghue lab (Harvard Herbaria) for advice and support. We wish to thank the curators of $\mathrm{B}, \mathrm{C}$, CUP, FH, G, GOET, H, K, L, PC, PRM, S, TRTC, TUR, TURA, for arranging loans of material, Betty Klug-Andersen, Henry Dissing, Steen A. Elborne, Jakob HeilmannClausen, Sven-Åke Hanson, Roy Kristiansen, Christian Lange, Jens H. Petersen, Trond Schumacher, Anne Storgaard, James Trappe, Jukka Vauras, Nancy Weber and Wulfard Winterhoff for providing specimens, Keith Egger for sharing data and results before publication, Niels Daugbjerg and Ole Seeberg for sharing knowledge and assisting in part of the phylogenetic analysis, Leif Bolding for help with the graphics in FIGS. 22-24, Steen A. Elborne, David S. Hibbett, Roy Kristiansen, and Jens H. Petersen for supplying photographs, J. H. Petersen for scanning the color photographs, and two anonymous reviewers for their insightful comments on the paper. We thank Michael Castellano, Daniel Luoma and the US Forest Service, Oregon State University for permission to reproduce the photographs in FIGS. 14 AND 17-19, and Sara Landvik, Novozymes A/S, for doing the PCR and sequencing of the LSU of $P$. vesiculosa added after acceptance of the paper. Funding was provided by an NSF grant (DEB-9521944) to DHP and by a grant from the Faculty of Science, University of Copenhagen to $\mathrm{KH}$.

\section{LITERATURE CITED}

Arpin N. 1969. Les caroténoïdes des Discomycètes: essai chimiotaxinomique. Bull Mens Soc Linn Lyon 38(suppl.): 1-169.

Auerswald B. 1869. Sarcosphaera Awd., novum genus Discomycetum. Hedwigia 6:82-83.

Beaton G, Weste G. 1982. Australian hypogaean Ascomycetes. Trans Brit Mycol Soc 79:455-468.

Berthet P. 1964a. Essai biotaxinomique sur les Discomycètes [Thèses]. Lyon: Joanny Lorge. 157 p.

- 1964b. Formes conidiennes de divers Discomycètes. Bull Soc Mycol France 80:125-149.

1970. Les ornementations sporales méconnues de cinq especes de Discomycètes opercules. Extrait du bulletin mensuel de la Société linnéenne de lyon 39:289292.

Boudier JLÉ. 1879. On the importance that should be attached to the dehiscence of asci in the classification of the discomycetes. Grevillea 8:45-49.

. 1885. Nouvelle classification naturelle des Discomycètes charnus connus gènèralement sous le nom de Pézizes. Bull Soc Mycol France 1:91-120.

. 1899. Note sur quelques champignons nouveaux des environs de Paris. Bull Soc Mycol France 15:49-54. . 1905-1910. Icones Mycologicae. Vols. 1-4. Paris. 362 p., 600 pl.

. 1907. Histoire et classification des Discomycètes d'Europe. Paris: Klincksieck. 221 p. 
Brummelen J van. 1967. A world-monograph of the genera Ascobolus and Saccobolus (Ascomycetes, Pezizales). Persoonia suppl. 1. $260 \mathrm{p}$.

- 1978. The operculate ascus and allied forms. Persoonia 10:113-128.

- 1998. Two bizarre ascus apices of Pezizales revealed by their ultrastructure. Cryptogamie Bryol Lichén 19: 257-265

Bulliard JBF. 1791. Historie des champignons de la France. 1. Paris. 504 p.

Burdsall HH. 1968. A revision of the genus Hydnocystis (Tuberales) and of the hypogeous species of Geopora (Pezizales). Mycologia 60:496-525.

Chatin A. 1891. Contribution a l'histoire naturelle de la truffe. Compt Rend Acad Sci. Paris 111:947-953.

Cooke MC. 1877. New British fungi. Grevillae 6:71-76.

Corda ACJ. 1854. Icones fungorum hucusque cognitorum. In: Zobel JB, ed. Praha 6:1-86.

Curry KJ, Kimbrough JW. 1983. Septal structures in apothecial tissues of the Pezizaceae (Pezizales, Ascomycetes). Mycologia 75:781-794.

Dennis RWG. 1981. British Ascomycetes. 4th ed. Vaduz: Cramer. 585 p.

- 1983. Typification of Peziza (Ascomycetes: Pezizales). Kew. Bull. 37:643-652.

Dillenius JJ. 1719. Cathalogus plantarum circa Gissam sponte nascentium. Cum appendice. Francofurti ad Moenum. 480 p., 16 pl.

Dissing H. 2000. Pezizales. In: Hansen L, Knudsen H, eds. Nordic macromycetes 1. Copenhagen: Nordsvamp. 309 p.

- Korf RP. 1980. Preliminary studies in the genera Ruhlandiella, Sphaerosoma, and Sphaerozone (order Pezizales). Mycotaxon 12:287-306.

— zaceae (Pezizales). Nordic J Bot 1:102-108.

- Schumacher T. 1979. Preliminary studies in the genus Boudiera, taxonomy and ecology. Norw J Bot 26: 99-109.

Donadini JC. 1977. Le genre Peziza L. per Saint-Amans (I). Bull Soc Linn Provence 30:37-92.

. 1978. Le genre Peziza L. per Saint-Amans (II). Les Pezizes de Haute-Provence et de Dauphiné-Savoie. Bull Soc Linn Provence 31:9-36.

— 1979a. Le genre Peziza Linné per Saint-Amans (lére Partie). Documents mycologiques 9:1-42.

- 1979b. Le genre Peziza Linn. per St. Amans (groupe de Peziza badia). Documents mycologiques 10:48-58.

- 1979c. Un genre nouveau: Greletia nov. gen. (ex

Pulparia Karsten emend. Korf pro parte. Pezizales).

Bull Soc Mycol France 95:181-184.

1980a. Le genre Peziza. III. Sous-genre Galactinia.

Bull Soc Mycol France 96:239-246.

—. 1980b. Le genre Peziza (Dill.) Linné per Saint Amans sous-genre Pachyella (Boudier) nov. comb. Documents mycologiques 11:25-26.

- 1985. Le genre Peziza dans le sud-est de la France complements (1) avec extension a l'Europe. Bull Soc Linn Provence 35:153-166.

Dumortier BCJ. 1829. Analyse des familles des plantes, avec l'indication des principaux genres qui s'y rattachent. Tournay, Belgium: J. Casterman, aine. 104 p.

Eckblad F-E. 1968. The genera of the operculate Discomycetes. A re-evaluation of their taxonomy, phylogeny and nomenclature. Nytt Mag Bot 15:1-191.

Egger KN. 1987. The taxonomic value of phenoloxidase tests for separating Peziza and Plicaria (Pezizales). Mycotaxon 29:183-188.

Elliott ME, Kaufert M. 1974. Peziza badia and Peziza badioconfusa. Can J Bot 52:467-472.

Eriksson OE. 2000. Outline of the Ascomycota 2000. Myconet. http://www.umu.se/myconet/Myconet.html

- Hawksworth DL. 1995. Notes on ascomycete systematics-Nos 1885-2023. Syst Ascomycetum 14:41-77.

Felsenstein J. 1984. Distance methods for inferring phylogenies: a justification. Evolution 38:16-24.

Fischer E. 1938. Tuberineae. In: Engler A, Harms H. eds. Nat. Pflanzenfam. 2nd. ed. 5b(8):1-42. Leipzig: Engelmann W.

Fries EM. 1822. Systema mycologicum. II. Lundae. 621 p.

Fuckel L. 1870. Symbolae mycologicae. Beiträge zur kenntnis der rheinischen pilze. Jb Nassau Ver Naturk 23-24: $1-459$.

Galán R, Moreno G. 1998. Ruhlandiella berolinensis, an exotic species in Europe. Mycotaxon 68:265-271.

Gamundi IJ, Ranalli ME. 1964. Estudio sistemático y biológico de las Ascoboláceas de Argentina. I. Nova Hedwigia 7:517-533.

Gilkey HM. 1916. A revision of the Tuberales of California. University of California publications in Botany 6:275356.

- 1954a. Taxonomic notes on Tuberales. Mycologia 46:783-793.

— 1954b. Tuberales. N Am Flora. II 1:1-36.

Ginns J. 1980. Peziza badioconfusa. Fungi Canadensis 168. 2 p.

Graybeal A. 1998. Is it better to add taxa or characters to a difficult phylogenetic problem? Syst Biol 47:9-17.

Hansen K, Sandal SK, Dissing H. 1998. New and rare species of Pezizales from calcareous woodlands in Denmark. Nordic J Bot 18:611-626.

- Pfister DH, Hibbett S. 1999. Phylogenetic relationships among species of Phillipsia inferred from molecular and morphological data. Mycologia 91:299-314.

Harmaja H. 1986. Studies on the Pezizales. Karstenia 26:4148.

Harrington FA, Pfister DH, Potter D, Donoghue MJ. 1999. Phylogenetic studies within the Pezizales I. 18S rRNA sequence data and classification. Mycologia 91:41-50.

Hawker L. 1954. British hypogeous fungi. Philos Trans R Soc London 237:429-546.

Hawksworth DL, David JC. 1989. Family names. Index of fungi supplement. Wallingford, UK: International Mycological Institute. $75 \mathrm{p}$.

- Kirk PM, Sutton BC, Pegler DN. 1995. Ainsworth and Bisby's dictionary of the fungi. 8th ed. Wallingford, UK: CAB International. 616 p.

Hennebert GL. 1973. Botrytis and Botrytis-like genera. Persoonia 7:183-204.

- Korf RP. 1975. The peat mould, Chromelosporium ollare, conidial state of Peziza ostracoderma, and its mis- 
applied name, Botrytis crystallina, Botrytis spectabilis, Ostracoderma epigaeum and Peziza atrovinosa. Mycologia 67:214-240.

Hennings P. 1903. Ruhlandiella berolinensis P. Henn. n. gen. et n. sp., eine neue deutsche Rhizinacee. Hedwigia 42: 22-24.

Hirsch G. 1980. Beiträge zur Kenntnis der Gattung Boudiera CKE. (Pezizales, Ascomycetes). I. Eine Boudiera-Kollektion aus der DDR und ihre Stellung zu den bisher bekannten Arten. Wiss. Z. Friedrich Schiller-Univ. Jena Math.-nat. Reihe 29:649-655.

. 1984. Studies in the Pezizaceae. 1. Introduction. 2. Peziza apiculata and its relatives. Mycotaxon 19:57-69.

- 1985. The genera Scabropezia and Plicaria in the German Democratic Republic. Agarica 6:241-258.

- 1992. Über einige Peziza-arten mit rötlichen Pigmenten. Boletus 16:3-9.

Hohmeyer H. 1986. Ein Schlüssel zu den europäischen Arten der Gattung Peziza L. Z Mykol 52:161-188.

Häffner J. 1995. Pseudoapiculate und apiculate Becherlinge-Emendation. (Rezente Ascomycetenfunde 16). Rheinland-Pfälzisches Pilzjournal 5:4-31.

Karsten PA. 1869. Monographia Pezizarum fennicarum. Notiser ur Sällskapets pro Fauna et Flora Fennica Förhandlingar 10:99-206.

Khan AZMNA. 1976. Peziza natrophila sp. nov. Trans Brit Mycol Soc 67:540-543.

Kimbrough JW. 1970. Current trends in the classification of Discomycetes. Bot Rev 36:91-161.

- 1994. Septal ultrastructure and ascomycete systematics. In: Hawksworth DL, ed. Ascomycete systematics: problems and perspectives in the nineties. New York: Plenum Press. p 127-141.

— Curry KJ. 1985. Septal ultrastructure in the Ascobolaceae (Pezizales, Discomycetes). Mycologia 77:219229.

— Korf RP. 1967. A synopsis of the genera and species of the tribe Theleboleae (= Pseudoascoboleae). Amer J Bot 54:9-23.

—, Wu C-G, Gibson JL. 1991. Ultrastructural evidence for a phylogenetic linkage of the truffle genus Hydnobolites to the Pezizaceae (Pezizales, Ascomycetes). Bot Gaz 152:408-420.

Kishino H, Hasegawa M. 1989. Evaluation of the maximum likelihood estimate of the evolutionary tree topologies from DNA sequence data, and the branching order in Hominoidea. J Mol Evol 29:170-179.

Korf RP. 1954. Discomyceteae exsiccatae, Fasc. I. Mycologia 46:873-841.

- 1960. Nomenclatural notes. IV. The generic name Plicaria. Mycologia 52:648-651.

- 1972. Synoptic key to the genera of the Pezizales. Mycologia 64:937-994.

- 1973a. Sparassoid ascocarps in Pezizales and Tuberales. Rept Tottori Mycol Inst 10:389-403.

. 1973b. Discomycetes and Tuberales. In: Ainsworth GC, Sparrow FK, Sussmann AS, eds. The fungi, an advanced treatise 4. New York: Academic Press. p 249319. 1973c. On Boudier's genus Lepidotia (Pezizaceae). Persoonia 7:205-212.

— Z Zhuang W-Y. 1991. Kimbropezia and Pfistera, two new genera with bizarre ascus apices (Pezizales). Mycotaxon 40:269-279.

Kotlaba F, Pouzar Z. 1963. Two rare arenicolous fungi in Czechoslovakia: Psathyrella ammophila (Dur. et Lév.) P. D. Orton and Sarcosphaera ammophila (Dur. et Mont.) Moesz. Česká Mykol 17:71-76.

Kristiansen R, Schumacher T. 1993. Nye operkulate begersopper i Norges flora. Blyttia 51:131-140.

Krug JC, Jeng RS. 1984. Hapsidomyces, a new genus of the Pezizaceae with ornamented ascospores. Mycologia 76: 748-751.

Landvik S. 1996. Neolecta, a fruit-body-producing genus of the basal ascomycetes, as shown by SSU and LSU rDNA sequences. Mycol Res 100:199-202.

_ dinal classification of the Pezizales (Ascomycota): phylogenetic analysis of SSU rDNA sequences. Nordic J Bot 17:403-418.

— Eriksson OE, Gargas A, Gustafsson P. 1993. Relationship of the genus Neolecta (Neolectales ordo nov., Ascomycotina) inferred from 18S rDNA sequences. Syst Ascomycetum 11:107-118.

— Kristiansen R, Schumacher T. 1998. Phylogenetic and structural studies in the Thelebolaceae (Ascomycota). Mycoscience 39:49-56.

Le Gal M. 1937. Florule mycologique des Bois de la Grange et de l'Etoile. Discomycètes. Rev Mycol 2:197-222.

- 1941. Les Aleuria et les Galactinia. Paris. Rev Mycol Suppl 6:56-82.

- 1947(reprint 1970). Recherches sur les ornamentations sporales des discomycètes operculés. Bibliotheca mycologica 28:73-297.

- 1953a. Les Discomycètes de Madagascar. Prodr Flore Mycol Madagascar 4:1-465.

-. 1953b. Les Discomycètes de l'herbier Crouan. Rev Mycol 18:73-132.

- 1960. Flore iconographique des champignons du Congo. 9 fasc: Discomycetes. Bruxelles. p 167-183, pl 29-31.

- 1962. Combinaisons nouvelles concernant les genres Galactinia (Cooke) Boud. emend. Le Gal, Scutellinia (Cooke) Lamb. emend. Le Gal et Sarcosoma Casp. Bull Soc Mycol France 78:204-216.

Linnaeus C. 1753. Species plantarum. Holmiae. 1200 p.

Maas Geesteranus RA. 1967. De Fungi van Nederland II. Pezizales-deel I. Wetenschap Mededel Konin Nederl Natuurhist Veren 69:1-84.

Maddison DR, Ruvolo M, Swofford DL. 1992. Geographic origins of human mitochondrial DNA: phylogenetic evidence from control region sequences. Syst Biol 41: 111-124.

Maddison WP. 1993. Missing data versus missing characters in phylogenetic analysis. Syst Biol 42:576-581.

—, Maddison DR. 1992. MacClade: analysis of phylogeny and character evolution. Version 3. Sinauer Associates, Sunderland, Massachusetts.

Maia LC, Yano AM, Kimbrough JW. 1996. Species of Asco- 
mycota forming ectomycorrhizae. Mycotaxon 57:371390.

Medel R, Guzmán G, Chacón S, Korf RP. 1996. Iodowynnea, a new genus of the Pezizales known from Africa and tropical America. Mycotaxon 59:127-135.

Moncalvo J-M, Lutzoni FM, Rehner SA, Johnson J, Vilgalys R. 2000. Phylogenetic relationships of agaric fungi based on nuclear large subunit ribosomal DNA sequences. Syst Biol 49:278-305.

Moravec J. 1985. A taxonomic revision of species related to Peziza apiculata. Agarica 6:56-66.

. 1987. A taxonomic revision of the genus Marcelleina. Mycotaxon 30:473-499.

- 1994. Some new taxa and combinations in the Pezizales. Czech Mycol 47:261-269.

—, Spooner BM. 1988. Peziza vacinii (Pezizales), with notes on taxonomy of related brown-spored species. Trans Brit Mycol Soc 90:43-48.

Moreno G, Díez J, Manjón JL. 2000. Picoa lefeburei and Tirmania nivea, two rare hypogeous fungi from Spain. Mycol Res 104:378-381.

Moser H. 1963. Ascomyceten. In: Gams IH, ed. Kleine Kryptogamenflora 2a. Innsbruck. $147 \mathrm{p}$.

Nei M. 1987. Molecular evolutionary genetics. New York: Columbia University press. $512 \mathrm{p}$.

Norman JE, Egger KN. 1996. Phylogeny of the genus Plicaria and its relationship to Peziza inferred from ribosomal DNA sequence analysis. Mycologia 88:986-995.

1999. Molecular phylogenetic analysis of $P e^{-}$ ziza and related genera. Mycologia 91:820-829.

Nylander W. 1868. Observationes circa Pezizas Fennicae. Notiser ur Sällsk pro fauna et flora Fennica Förh 9:197.

O'Donnell K, Beneke S. 1973. Apothecial formation by $P e-$ ziza quelepidotia in pure culture. Mycologia 65:913-915.

—, Cigelnik E, Weber NS, Trappe JM. 1997. Phylogenetic relationships among ascomycetous truffles and the true and false morels inferred from $18 \mathrm{~S}$ and $28 \mathrm{~S}$ ribosomal DNA sequence analysis. Mycologia 89:48-65.

Olmstead RG, Bremer B, Scott KM, Palmer JD. 1993. A molecular systematic analysis of the Asteridae sensu lato based on $r b c \mathrm{~L}$ sequences. Ann Missouri Bot Gard 80: $700-722$.

Olsen GJ, Matsuda H, Hagstrom R, Overbeek R. 1994. fastDNAml: a tool for construction of phylogenetic trees of DNA sequences using maximum likelihood. CABIOS 10:41-48.

Paden JW. 1972. Imperfect states and the taxonomy of the Pezizales. Persoonia 6:405-414.

- 1973. The conidial state of Peziza ammophila. Can J Bot 51:2251-2252.

Percudani R, Trevisi A, Zambonelli A, Ottonello S. 1999. Molecular phylogeny of truffles (Pezizales: Terfeziaceae, Tuberaceae) derived from nuclear rDNA sequence analysis. Mol Phylogenet Evol 13:169-180.

Persoon CH. 1801. Synopsis Methodica Fungorum. Gottingae. $706 \mathrm{p}$.

Petersen PM. 1967. Studies on ecology of some species of Pezizales. Bot Tidsskr 62:312-322.
1970. Changes of the fungus flora after treatment with various chemicals. Bot Tidssk 65:264-280.

- 1985. The ecology of Danish soil inhabiting Pezizales with emphasis on edaphic conditions. Opera Bot 77:1-38.

Pfister DH. 1973. The psilopezioid fungi. IV. The genus Pachyella (Pezizales). Can J Bot 51:2009-2023.

_ 1974. Notes on Caribbean Discomycetes. V. A preliminary annotated checklist of the Caribbean Pezizales. Jour Agric Univ Puerto Rico 58:358-378.

- 1979a. Type studies in the genus Peziza V. Species described by Rehm. Mycotaxon 8:187-192.

- 1979b. Type studies in the genus Peziza VIII-X. Species described by G. Massee, E. K. Cash and F. J. Seaver. Mycotaxon 9:501-504.

- 1991. A redescription of Peziza bananicola and comments on some similar tropical species. Mycotaxon 41: 505-507.

Platt JL, Spatafora JW. 2000. Evolutionary relationships of nonsexual lichenized fungi: molecular phylogenetic hypotheses for the genera Siphula and Thamnolia from SSU and LSU rDNA. Mycologia 92:475-487.

Pouzar Z. 1972. Sarcosphaera crassa (Santi ex Steud.) Pouz., the correct name for Sarcosphaera coronaria (Jacq. ex M. C. Cooke) J. Schroet. (Pezizaceae). Ceská Mykol 26: 32-36.

Rehm H. 1894. Ascomyceten: Hysteriaceen und Discomyceten. In: Rabenhorst GL, ed. Kryptogamen-Flora von Deutschland, Oesterreich und der Schweiz, I-III. Leipzig: Eduard Kummer. p 913-1040.

Rifai MA. 1968. The Australasian Pezizales in the herbarium of the Royal Botanic Gardens Kew. Verh Kon Ned Akad Wetensch, Afd Natuurk, Tweede Sect 57:1-295.

Romagnesi H. 1978. Les espèces du genre Peziza St-Am. (= Aleuria ss. Boud. et Galactinia Cke ss. Boud.). Bull Trimestriel Féd Mycol Dauphiné-Savoie 18:19-23.

Samuelson DA. 1978. Asci of the Pezizales. I. The apical apparatus of iodine-positive species. Can J Bot 56:18601875.

Schumacher T, Jenssen KM. 1992. Discomycetes from the Dovre mountains, Central South Norway. In: Gulden G, Jenssen KM, Stordal T. eds. Arctic and Alpine Fungi 4. Oslo: Soppkonsulenten A/S. 66 p.

Seaver FJ. 1928. The North American cup-fungi (operculates). New York: Hafner Publishing Co, Inc. 377 p.

Svrček M. 1969. Neue Gattungen operculater Discomyceten. Česká Mykol 23:90-96.

- 1970. Über einige arten der Discomycetengattung Peziza [Dill.] L. ex St-Amans. Česká Mykol 24:57-76.

Swofford DL. 1998. PAUP*. Phylogenetic Analysis Using Parsimony (* and Other Methods). Version 4. Sinauer Associates, Sunderland, Massachusetts.

Thiers HD. 1984. The secotioid syndrome. Mycologia 76:1-8. Trappe JM. 1971. A synopsis of the Carbomycetaceae and Terfeziaceae (Tuberales). Trans Brit Mycol Soc 57:8592.

- 1975a. Generic synonyms in the Tuberales. Mycotaxon 2:109-122.

- 1975b. The genus Amylascus (Tuberales). Trans Brit Mycol Soc 65:496-499. 
1979. The orders, families, and genera of hypogeous Ascomycotina (truffles and their relatives). Mycotaxon 9:297-340.

1989. Cazia flexiascus gen. et sp. nov., a hypogeous fungus in the Helvellaceae. Mem New York Bot Gard 49:336-338.

, Beaton G. 1984. Mycoclelandia nom. nov. (hypogeous Ascomycotina), a replacement for the pre-empted generic name Clelandia. Trans Brit Mycol Soc 83:535536.

, Maser C. 1977. Ectomycorrhizal fungi: interactions of their research by mushrooms and truffles with beast and trees. In: Walters T, ed. Mushrooms and man, an interdisciplinary approach to mycology. Albany, Oregon: Linn-Benton Community College. p 165-179.

Trimbach J. 1999. Novitates. Documents Mycologiques 29(113):8

Tulasne L-R, Tulasne C. 1843. Champignons hypogés de la famille des Lycoperdacees, observés dans les environs de Paris et les départemens de la Vienne et d'Indre-etLoire. Annales des Sciences Naturelles Serie 2, 19:373381.

1844. Fungi nonnulli hypogaei, novi v. minus cogniti. Giornale Botanico Italiano parte 1 (2):5564.

1851. Fungi hypogaei. Paris: Friedrich Klincksieck. 222 p.
Wakefield EM. 1939. Nomina generica conservada, contributions from the Nomenclature Committee of the British Mycological Society. II. Trans Brit Mycol Soc 23: 281-292.

Warcup JH. 1990. Occurrence of ectomycorrhizal and saprophytic discomycetes after a wild fire in a eucalypt forest. Mycol Res 94:1065-1069.

- Talbot PHB. 1989. Muciturbo: a new genus of hypogeous ectomycorrhizal Ascomycetes. Mycol Res 92: 95-100.

Weber NS, Trappe JM, Denison WC. 1997. Studies on Western American Pezizales. Collecting and describing ascomata-macroscopic features. Mycotaxon 61:153-176.

Webster J, Rifai MA, Samy El-Abyad S. 1964. Culture observations on some discomycetes from burnt ground. Trans Brit Mycol Soc 47:445-454.

Wells WL, Kempton PE. 1967. Studies on the fleshy fungi of Alaska. I. Lloydia 30:258-268.

Wiens JJ. 1998. Does adding characters with missing data increase or decrease phylogenetic accuracy? Syst Biol 47:625-640.

Yao YJ, Spooner BM, Hawksworth DL. 1995. Author citation of the generic name Peziza (Pezizales, Pezizaceae). Syst Ascomycetum 14:17-24.

Zhuang W-Y, Korf RP. 1986. A monograph of the genus Aleurina Massee (= Jafneadelphus Rifai). Mycotaxon 26:361-400. 